\title{
From Warriors to Urban Dwellers
}

Ascari and the Military Factor in the Urban Development of Colonial Eritrea

Des guerriers devenus résidents urbains. Les ascaris et le facteur militaire dans le développement urbain de l'Érythrée

\section{Uoldelul Chelati Dirar}

\section{CpenEdition}

\section{Journals}

Electronic version

URL: http://journals.openedition.org/etudesafricaines/4717

DOI: $10.4000 /$ etudesafricaines. 4717

ISSN: $1777-5353$

\section{Publisher}

Éditions de l'EHESS

\section{Printed version}

Date of publication: 1 January 2004

Number of pages: $533-574$

ISBN: 978-2-7132-2004-3

ISSN: 0008-0055

\section{Electronic reference}

Uoldelul Chelati Dirar, « From Warriors to Urban Dwellers », Cahiers d'études africaines [Online],

175 | 2004, Online since 22 November 2013, connection on 01 May 2019. URL : http:// journals.openedition.org/etudesafricaines/4717; DOI : 10.4000/etudesafricaines.4717

This text was automatically generated on 1 May 2019.

(c) Cahiers d'Études africaines 


\title{
From Warriors to Urban Dwellers
}

\author{
Ascari and the Military Factor in the Urban Development of Colonial \\ Eritrea* $^{*}$ \\ Des guerriers devenus résidents urbains. Les ascaris et le facteur militaire dans \\ le développement urbain de l'Érythrée
}

\author{
Uoldelul Chelati Dirar
}

1 The aim of this article is to discuss the role played by the military component in the process of urbanisation which Eritrea experienced, between 1890 and 1941, under Italian colonialism. Two main points will be discussed. The first one is the role played by military priorities in determining lines of development in the early colonial urban planning in Eritrea. In this section I will analyse how the criteria of military defensibility, rather than economic or functional priorities, had a significant influence on the main patterns of early colonial settlements in Eritrea. The second point discussed in this article is the nature and extent of the interaction between colonial urban planning and Eritrean society. Here I will discuss how this interaction has reshaped the Eritrean social and economic landscape. In this context special attention will be given to the role of Eritrean colonial troops better known as ascari ${ }^{1}$. In fact, it is a key thesis of this article that Eritrean ascari played a crucial role in the composite set of relations and strategies which constituted the colonial milieu. Urban history of colonial Eritrea represents one of the preferred loci for the study of the development of the colonial milieu into which colonial soldiers were important actors as they were builders of social and territorial urban spaces.

2 A preliminary methodological remark which I would like to make is that the assessment of the real impact of Italian colonialism on Eritrean societies, both in terms of national identities and socio-economic development, is still a very controversial issue. The controversy turns on the assessment of the impact of colonialism on the history of the region, which is alternatively described in terms of a marginal accident in the longue durée of regional history or, on the opposite, as a substantial and dramatic rupture. This debate, which, to a certain extent, echoes the debate developed within post-colonial African historiography (Gann \& Duignan 1967; Oliver \& Atmore 1972; Hopkins 1973; Ajayi 1968, 
1981: 497-509), is not just academic bickering but also bears heavy political implications. In fact, supporters of the first thesis, by putting more emphasis on the elements of continuity under the shadow of Greater Ethiopia's narrative ${ }^{2}$, use this argument as a battering ram to unhinge the historical and political legitimacy of the state of Eritrea to exist $^{3}$. On the other side, supporters of the second theory anchor the development of Eritrean nationalism and the historical legitimacy of Eritrea to exist as an independent state, to the founding role of the colonial experience (Yemane Mesghenna 1988; Jordan Gebremedhin 1989; Yohannes Ogbazghi 1991; Ruth Iyob 1995; Bereketeab Redie 2000).

In the light of this controversy, the first point to be discussed is the very notion of urbanisation in the Eritrean context. In fact, a clear definition of the concept of urban centres and urbanisation in "pre-colonial Eritrea" is crucial if we have to assess elements of change and continuity in relation to the introduction of Italian colonial rule over the region. An enlightening example of the conceptual and methodological issue underlying this topic can be found in Eleonora Onnis' introduction to her thesis on the history of the town of Asmara, defended in 1957, where the author affirmed:

"The urban fact in Africa is strictly related to the European colonisation, even where indigenous pre-colonial centres existed. The only exception is Mediterranean Africa, where the old Islamic towns have their own history, their own past heritage that are reflected in their present adaptation. That gives an unmistakable mark to their present development, not really in the exterior aspect but rather on their rhythm of life" (ONNIS 1957: 4) (My translation).

5 This thesis, which yet stands as one of the most documented studies on the urban history of Asmara, clearly shows one of the main methodological problems in assessing urbanism in Africa, and in Eritrea in particular, which is a persistent neglect of pre-colonial urbanism $^{4}$. In the introduction to Africa's Urban Past, David Anderson and Richard Rathbone (2000: 9) stated that "urban history as a recognisable sub-field has not made a significant impact upon African historiography, and the reason for this needs to be addressed". To this regard Eritrea offers a striking and, to a certain extent, extreme example of this general trend in urban history in Africa. As a partial explanation of this attitude of scholars dealing with Eritrea, an important specificity of the Eritrean case needs to be recalled. It is a matter of fact that the prolonged warfare, which has devastated the region from the early 1960s to the final achievement of Eritrean independence in 1991, has affected not only the socio-economic transformation of Eritrea, but also its cultural and scholarly development. Throughout all those years it has been extremely difficult to conduct extensive and intensive research on Eritrean history and, when research has been possible, priorities in the identification of lines of research were dictated by historical contingencies, which pushed to focus on political and military issues ${ }^{5}$. This can explain why, to quote one of the "latest" detailed studies on Eritrea's urban history, we have to go back to 1957. In other words, an in-depth and updated study of the urban history of the region is still to be carried out ${ }^{6}$.

6 However, contrarily to what colonial ${ }^{7}$ and part of early post-colonial literature affirmed, the region corresponding to the present states of Eritrea and Ethiopia had experienced a long and intense indigenous tradition of urbanism which goes back to the $8^{\text {th }}$ century B.C. (Fattovich 1988: 92; Schmidt \& Curtis 2001). Archaeological investigations provide evidence showing that urban centres like the ancient port of Adulis (Anfray 1974) on the Red Sea, as well as the inland centres of Deqqi Mahari, Rora Laba (Conti Rossini 1922), Toqonda, Qohaito (Curtis \& Yosef Libsekal 1997: 20-21; Wenig 1997: 20-21), Matara, 
Kaskase (Tringali 1973-1977), Yeha, and Axum (Munro-Hay 1991: 44-48) were all part of a complex network of economic, military, and social exchanges, which had its extremities in present Southern Ethiopia, South-Eastern Sudan, the Mediterranean world and the Indian Ocean (ibid.: 58-59). The same archaeological evidence clearly shows the existence of important and organised urban centres all over the region (Conti Rossini 1903; Arkeil 1954; Munro-Hay \& Tringali 1993).

7 This trend continued till the $7^{\text {th }}$ century when this impressive and highly sophisticated civilisation started to decline. Previous historiography tended to explain this decline by attributing it to the allegedly disruptive impact of the rise of Islam. The Arabo-Islamic civilisation would have surrounded Christian Abyssinia excluding it from its traditional religious and economic networks (Conti Rossini 1928: 280). However, there is more and more evidence supporting the ecological and geopolitical factors as determining ones (Munro-Hay 1991: 258-260; Butzer 1981). The former one being related to the excessive pressure on the land which made difficult the production of adequate food for the population, and the latter to the lessened relevance of the Red Sea in the system of international trade, due to the shift of trade routes to the Gulf region (Chaudhuri 1985; Risso 1995).

are still serious gaps in the reconstruction of the history of the region encompassing present Eritrea between the $10^{\text {th }}$ and $16^{\text {th }}$ centuries. Nevertheless, it is possible to affirm that, though with discontinuity, due to different political and economic developments, urbanism continued to represent an important and tangible phenomenon in the history of the region, as demonstrated by archaeological evidences. Starting from the $13^{\text {th }}$ century, an interesting development marked the urban history of the region. Abyssinian kings, in order to ensure their political and economic hegemony over the region, were forced to devise new strategies which they thought were useful in overcoming obstacles related to logistical factors. In fact, due to inadequate infrastructures for the movement of people and goods, it was extremely difficult for the royal court to exert a real control over the territory they claimed and to have their authority acknowledged by the population. One of the strategies introduced by Abyssinian monarchs to partially solve this problem were the so-called "wandering capitals" (Horvath 1969). Those roving capitals, according to accounts of contemporary sources (De Almeida 1954; Lobo 1735), could be described as a sort of huge encampment, composed of the royal court, noblemen, soldiers with their families, and slaves that wandered in a cyclical way around the territory over which the sovereign claimed authority (Pankhurst 1982: [I] 41-47).

9 The main factors regulating the rhythm of those peregrinations were, on the one hand, the cyclical alternation of the rainy season, which affected the practicability of routes and, on the other hand, the harvest season. In fact, such a huge mass of people, which, according to contemporary sources, could reach up to 100,000 people (Hovarth 1969: 209), needed a substantial supply of food that it was not able to produce by itself, due to its nomadic nature. Therefore, the burden of feeding those "capitals" rested entirely on the shoulders of the local peasantry, which could not escape this ordeal. In fact, to run away at such a critical time of the rural calendar would have implied the complete loss of the harvest and, therefore, would have jeopardised the food security of the community for the coming year. From this point of view, the exercise of power of those "capitals" could be more appropriately described in terms of a systematic pillaging of unarmed rural populations, often spatially and culturally remote from the civilisation and society that 
those capitals represented. This pattern of predatory behaviour on the side of the army has persisted till modern time, marking for ever the nature of relations between the army and the civilian population (Caulk 1978).

10 A further development of this attitude based on the exercise of political authority through the deployment of troops can be found in the development of centres, which local traditions attribute to immigrants referred to as Loggo and Chewa (Ayele TekleHaymanot 1965). Those originally were military settlements sent into the fringes of Abyssinian political power between the $14^{\text {th }}$ and $15^{\text {th }}$ centuries ${ }^{8}$ to exert political and territorial control over populations otherwise recalcitrant to central power and rather inclined to claim their own sovereignty (Conti Rossini 1904). Those military garrisons developed into permanent settlements through intermarriage with local population, and traces of these settlements can still be identified in different regions of Eritrea's highlands?.

11 Between the $15^{\text {th }}$ and $17^{\text {th }}$ centuries, two important developments marked the urban history of the region. The first one is the growth of new urban centres in the region of present Eritrea, whose origins can be traced back to the late medieval period. This is the case of centres like Debarwa (Pankhurst 1982: [I] 65), Digsa Asmara (ibid.: 73-74), Massawa and Hirghigo (ibid.: 80). This flourishing of urban centres reflects the development of new important centres of political and economic power which marked the history of the region till the late $18^{\text {th }}$ century. Debarwa and Digsa played a central role in the region as seats of the Bahr Negash (Lord of the Sea), a title which designated the ruler of the region stretching from the present Eritrean highlands to the coast of the Red Sea. Similarly Hirghigo and Massawa played a major role as seats of the Na'ib, a title indicating the main political authority along the coastal area and the eastern escarpments of Eritrea. In a broader context all those centres had their main material source of power in their being located along some of the most vital trading routes feeding the long distance trade between the coast of the Red Sea and the inland ${ }^{10}$.

12 Another relevant development in the urban history of the region was the establishment of the town of Gondar as capital of the Abyssinian court in 1636 (Pankhurst 1982: [I] 115). This had a significant impact on the urban history of the region, since Gondar acted for a long time as a dynamic economic and cultural centre. The establishment of Gondar had also a particular impact on the Christian population, as Gondar became a key religious and cultural centre, where people of Christian background, looking for higher education, used to go until the colonial period (Teshome Wagaw 1979: 11). However, already in the second half of the $18^{\text {th }}$ century the political and administrative primacy of Gondar in the region had already been undermined by the development of centrifugal forces which led to a high degree of regional instability (Abir 1968: 30-33; Tadesse Beyene 1990). This is probably an important factor that can contribute in explaining the decadence of many urban centres in the region. New developments in Northeast Africa during the $19^{\text {th }}$ century further accentuated that trend toward political fragmentation and urban decadence. In particular, the territory of present Eritrea, where converged the conflicting hegemonic ambitions of Egypt ${ }^{11}$, Ethiopia (Caulk 1971), and, later on, Italy, was ravaged by continuous warfare that depleted its human and material resources (Pankhurst 1968: 572-576).

13 An additional factor which contributed in making the life of ordinary people extremely difficult and precarious was banditry or sheftennät ${ }^{12}$. A traditional instrument of social mobility to which cadets of noble-family or ambitious common people resorted in order 
to improve their social status, Sheftennät, became, in the second half of the $19^{\text {th }}$ century, a widespread phenomenon, marked by continuous and often unpredictable shifts of alliances (Fernyhough 1986). Warfare, instability, and the deriving insecurity of roads hampered the regular movement of goods and people, and limited the volume of economic exchanges, making the development of strong and structured urban centres (Pankhurst 1968: 573) much more difficult ${ }^{13}$.

Finally, what affected urbanism dramatically in the region was the disastrous Great Famine that ravaged the region between 1888 and 1892. This famine was the result of the simultaneous devastating impact of epidemics, drought, locust swarms and caterpillar pest (Pankhurst 1985: 69). The most devastating factor was the epidemic of rinderpest, which was spread by infected donkeys and mules brought from India by the Italian army to conduce its campaign of colonial expansion in the region (ibid.: 59). In a few months an estimated $90 \%$ of the cattle were infected and died, leaving pastoralist communities destitute and peasants deprived of oxen for ploughing. As a result, many villages were deserted (Wylde 1970: 127) and their surviving inhabitants forced into migration to areas where food and job opportunities were available ${ }^{14}$.

It is in this devastated scenario, marked by a high degree of social and political instability, that the beginning of Italian colonial presence in Eritrea has to be collocated. The demographic collapse caused by the Great Famine, together with widespread political fragmentation, made it impossible to establish lasting and effective political systems, and, consequently, made also impossible the development of a strong and cohesive anticolonial opposition. On the opposite, this situation facilitated colonial penetration into Eritrea by making possible the implementation of an ambiguous, but effective, policy of alliances based on the principle of divide et impera. In fact, the early Italian colonial administration devised successful policies of social and political manipulation revolving around ethnicity, religion, and social stratification which, on the long term, also had a significant impact on the process of urbanisation.

\section{Periodisation for Colonial Urbanism}

Moving to colonial urbanism, the first methodological priority is to draft a tentative periodisation for patterns of urbanisation in colonial Eritrea. Though the process of urbanisation during the colonial period was quite complex, it is possible to divide it into two main phases: the Early period or Liberal (from 1885 to early 1920s) and the Fascist period, from the late 1920s to the crumbling of the Italian colonial "Empire" of East Africa in 1941.

\section{The Liberal Period}

17 To begin with, it has to be specified that, notwithstanding the traditional narrative focusing on the improvised nature of Italian colonialism (Del Boca 1976-1984; Miege 1976; Maione 1979), a more analytical and articulate approach is required. It is in fact apparent that, in spite of the undoubtedly weak and relatively underdeveloped nature of its metropolis, Italian colonialism had its own internal consistency, which can be detected in many of its policies. This is particularly true when it comes to issues like urban planning. From this point of view, the early colonial phase, which is known also as the "Liberal" 
period, could be further divided into two periods: first from 1885 to 1900 , and second from 1901 to the 1920 s.

The first period was characterised by a long and difficult process of administrative and political consolidation of territorial acquisitions. In this context colonisation was strictly related to "pacification" and control of the territory. For early Italian colonisers, Eritrea was a sort of virgin territory, an unknown land, which needed to be occupied, mapped and transformed, moulded in accordance with the needs of the newcomers ${ }^{15}$. In the original Italian plans, Eritrea was expected to become an outlet for the masses of destitute Italian farmers (Yemane Mesghenna 1988: 101-105), as well as a gateway to further expansion southward to Ethiopia. Therefore, to guarantee a safe and viable territory was the foremost priority. Safe and regular access to water, roads and administrative institutions was vital for a successful colonisation, and that, in a situation of perduring spread instability, could be insured only by the military (Rainero 1960: 45; Apollonio 1993: 128).

Heavily influenced by those contingencies, the development of urban centres in the early years of Italian colonial rule was to a certain extent artificial, as it did not reflect an economic or political development internal to the local society and was not even directly linked with any economic rationale on the part of the first nuclei of Italian settlers. It is in fact apparent that, at this stage, the determining factor in the identification of areas for colonial settlement was its military defensibility, which was assessed in terms of access to water and control of commanding locations (Baratieri 1988: 153). In other words, the landscape could be defined as the dictating factor in this early process of colonisation. As a consequence, main urban centres were developed around military fortifications. It was the case of the area of Bet Makha'e in Asmara, where the homonymous fort was built on top of the hill ${ }^{16}$. From Bet Makha'e started the expansion of a network of fortified centres which had Asmara as its ideal centre, and pivoting around it the towns of Keren, Agordat, Addi Ugri and Saganeiti, developed following the same military criteria (Zagnoni 1993: 150). The predominance of the military in the early administration and planning of colonial Eritrea is demonstrated also by the fact that, though Eritrea was officially declared an Italian colony on 1 January 1890 , with Massawa as its capital, it was only in 1897 that the first civilian governor of the colony was appointed, in the person of Ferdinando Martini ${ }^{17}$.

Starting from the end of the $19^{\text {th }}$ century, some substantial changes can be noticed in urban policies of Italian colonialism in Eritrea. After the first pioneering years, marked by repeated clashes with neighbouring Ethiopia and internal rebellion against colonial land policies (Tekeste Negash 1986; Caulk 1986), the colonial administration started enjoying a period of relative peace, marked by substantial changes in the organisation of urban areas. An important change was the transfer of the capital of the colony from Massawa to Asmara in $1899^{18}$. Another episode that gave Italian urban planners the possibility to redesign the urban space of Asmara was an accidental fire in 1900, which caused the destruction of some 300 shelters in the indigenous district. This incident allowed colonial urban planners to reorganise the indigenous area in accordance with more European criteria (Onnis 1957: 176). However, the real starting point of this new trend was marked by the Decreto Reale (Royal Decree) no. 259 issued on 30 July 1901, which dealt with the granting of land for building purposes (Mori 1914: Vol. IV 653). This decree is important for two main reasons. First, it made the granting of land for building purposes conditional on the preparation of urban development plans. Second, it sanctioned a significant 
administrative anomaly by stating that decisions regarding the organisation of the territory and of urban areas in the colony were to be taken directly by the colonial administration and not by the Parliament. By so doing, the Decreto Reale no. 259 provided the colonial administration with a high degree of decisional autonomy, which, however, was counterbalanced by substantial budgetary constraints. In fact, the financial administration of the colony remained included in the main budget of the Ministry of Foreign Affairs and it was only in 1908 that the Italian government authorised a separate budget for the Colony, subject to the approval of the Parliament ${ }^{19}$.

21 The impact of the Decreto Reale no. 259 on urban policies is attested by the subsequent release of master plans for the main Eritrean urban centres. To mention some of them: Asmara in $1902^{20}$, Agordat ${ }^{21}$ and Keren in $1903^{22}$, the second part of Asmara's master plan in $1908^{23}$ and Adi Qayyeh in $1909^{24}$. Significantly enough, as pointed out by the Italian scholar Stefano Zagnoni (1993: 151), the main lines of the early development of urban planning in Eritrea reflected partially the influence of the debate on the so-called "piccole città" ("small towns"), which had animated Italian intellectual milieus a few decades earlier. This debate, led by intellectuals like Carlo Cattaneo (1935) and Pacifico Valussi (1868), highlighted the relevance of the formation of small centres in what they defined as the best strategy for the establishment of organic links between main urban centres and rural areas ${ }^{25}$. The existence of this flow of social knowledge between the young Italian nation and its colonies is an interesting phenomenon which deserves further attention from scholars of Eritrea and Italian colonialism. In fact, it would be particularly interesting to investigate to what extent colonial urban planning has acted as a laboratory for the experimentation of new urban policies to be adopted later on in the colonial metropolis ${ }^{26}$. However, it has to be stressed that in this phase of colonial urban policies the process of formation of urban centres still tended to reflect more political and military priorities rather than the inner needs of a genuine economic development.

During the early years of Italian colonial rule over Eritrea, the dominant scheme for urban planning remained the orthogonal grid inherited by the ancient Roman urban tradition, with a substantial conceptual difference. In fact, in colonial urban planning the orthogonal grid was not considered as bound to infinite expansion, but, on the opposite, as spatially circumscribed and defined as an affirmation of colonial "order" vis-à-vis indigenous "disorder" (Zagnoni 1993: 151). In those years, for the first time, was also sanctioned the adoption of a partition of urban areas into zones. However, this partition was not based on a functional vision of urban planning but rather on a racial one. The process which led to this development is quite complex and deserves special attention. In fact, the first administrative materialisation of this new attitude toward colonial urban planning could be found in the Decreto governatoriale (Gubernatorial Decree) no. 798 of 23 October $1908^{27}$, which first sanctioned the partition of the town of Asmara into four zones, without providing any further detail about their nature and repartition ${ }^{28}$. It was only two months later that colonial legislators felt the need to specify the racial nature of the newly introduced zonal system. This was stated in the Decreto governatoriale no. 814 of 19 December 1908 which, adducing generic "reasons of public order", specified that the first zone was reserved to Italians and citizens of other [European] states, while in the second zone were allowed both Italians and sudditi coloniali (colonial subjects), or their equivalents ${ }^{29}$. The third zone was reserved exclusively to colonial subjects and their equivalents. Finally, the fourth zone was defined as the suburbs and later on became the industrial zone ${ }^{30}$. In the intentions of colonial urban planners, those zones were expected 
to be rigidly partitioned with a minimum of social interaction, though no clear instructions were given on how to implement this policy.

A further development of colonial urban policies in Eritrea was the Decreto Reale no. 378 of 31 January 1909, which systematised in an organic way all matters related to the use and ownership of land in the colony ${ }^{31}$. An important section of this decree, from article 82 to article 97, dealt with urban land, for which detailed rules concerning the allocation of urban land and its utilisation where defined. In the decree, particular emphasis was given to architectural and spatial criteria to be observed in erecting houses. In this context it must be emphasised that Art. 91 stated that the real ownership of urban buildings was to be acknowledged only once municipal authorities had ascertained the real compliance of the building with new urban regulations.

The next important event in Eritrea's urban planning was the release of master plans for the town of Asmara and Keren, which were drawn by engineer Cavagnari in 1914 ${ }^{32}$. The relevance of those plans, particularly the one for Keren, relies on the fact that, though they did not introduce any significant functional innovation, they deeply marked the topographic history of the two towns, and all subsequent plans had to refer to them (Onnis 1957: 193). The first aspect to be mentioned is that those plans reflected an urban growth now more linked to the real dynamism of the local economy, and no longer an artificial development piloted by colonial authorities ${ }^{33}$. However, the most important point is that the two master plans marked the beginning of a divergent pattern of urban development in which the European zone enjoyed a higher degree of urbanistic freedom, brightened by the presence of green areas and a more elaborate design of the space ${ }^{34}$. By contrast, the indigenous zone was subjected to a much stricter and plain geometric organisation of the space (Zagnoni 1993: 154). The release of those master plans also gave colonial legislators the opportunity to better define the racial nature of the organisation of urban spaces. In fact, Art. 5 of the Decreto Governatoriale (Gubernatorial decree) no. 1909 of 21 January 1914, which announced the release of Asmara's master plan, specified that Eritreans and colonial subjects in general were not allowed to own or inherit any property in the European zone, where they were not even allowed to reside anymore, except in the position of servants or relatives ${ }^{35}$. To set the matter straight the decree also disposed for the sale, within a year, of properties owned by indigenous inside the first zone.

It seems that the release of the new master plan provided the legislator with the opportunity to intervene on some of the recent urban developments, which colonial administrators perceived as unacceptable contradictions maturated inside the colonial urban space. The analysis of the releases of building permissions between the years 1908-1914 provides a clear and quite interesting map of urban growth in Eritrea, which supports this theory. In fact, for those years administrative records report a significant amount of building permissions given to individuals, which the colonial jurisdiction labelled as colonial subjects or assimilated ${ }^{36}$. According to those administrative records, a composite section of colonial subjects managed to make their way into the colonial urban space after the release of the 1908 master plans. Among them, traders (many were immigrants from the Arab peninsula), some former ascari, and also a substantial percentage of immigrants from Tegray, including many women ${ }^{37}$. Due to the unclear nature of earlier curban regulations, many of those applicants obtained land in areas which were inhabited by Europeans. It seems that urban regulations issued in 1914 tried to put an end to this trend by setting clearer and more explicit racial bars in the 
definition of patterns of urban development which could ultimately lead to the "legal" eviction of indigenous residents from areas now reserved to Europeans.

After this period of intensive reorganisation and development of urban areas, urban growth in Eritrea slowed down substantially, as the result of the reached balance among demographic growth, urban expansion and economic development (Onnis 1957: 195). That balance marked the urban history of Eritrea until the beginning of the activities for the preparation of the fascist invasion of Ethiopia of 1935.

\section{The Fascist Period}

Fascism introduced dramatic changes in Italian colonial policies, and this change is noticeable also in urban policies (Fuller 1991). Colonialism became a key component of the fascist regime's foreign policy (Di Nolfo 1966: Carocci 1969; Goglia \& Grassi (1981; Collotti et al. 2000) and played a great role in its symbolism of power (Mignemi 1988). Fascist propaganda used to put Italian colonial expansionism in a line of continuity with the colonial expansion of Ancient Rome and by so doing invested it with a mystical aura. In this perspective, urban planning became an important component of the fascist policy aimed at the establishment of a "total" society in which the image of an overwhelmingly and unchallengeably superior white race had to be affirmed through all possible means. In this context, architecture and urban planning were expected to play a central role in conveying and establishing, on a territorial basis, the totalitarian imperial dream of the fascist regime (Rava 1938). In the words of Enrico Rava ${ }^{38}$, one of the senior architects of the fascist period, urban planning was expected to become "not only art and science together, but the highest expression of the art of ruling" (Ciucci 1993: 109, my translation), of which the architect was expected to be the interpreter.

In the fascist perspective, architecture and urban planning were a sort of social laboratory, which was meant to inculcate the fascist totalitarian ideology both into metropolitan citizens and colonial subjects ${ }^{39}$. In the colonial territory this vision was asserted through a dichotomous discourse where the tidy, organised and disciplined European space was opposed to the indigenous space, perceived and described as messy, anarchic, and unruly. In other terms, the classical colonial discourse based on the contrast between "civilisation" and "barbarism" was proposed. Urban planning in the colonial territory had the additional task of disciplining not only the territory but also the indigenous population. In this context, to discipline essentially meant to wipe out the indigenous urban order, which was dumb for the deaf colonial architect that perceived it only in terms of disorder and filthiness ${ }^{40}$, deprived of any social rationale ${ }^{41}$. However, it is interesting to note that the main theorists of fascist urban planning, in spite of their negative perception of the indigenous organisation of the urban space, tried to incorporate some local architectural elements in their new master plans. Those local elements, once emptied of their original functional purpose, were proposed as decorative components, to add a local flavour to the fascist vision of the colonial space (Rava 1938: 1295). Nevertheless, this imperial dream of urban cleansing, which was partially implemented in Addis Ababa (Fuller 1996; Patassini 1993) and in other Ethiopian towns ${ }^{42}$, was much more difficult to implement in Eritrea. In fact, the Italian occupation of Eritrea had lasted longer and there the urban planning wished by fascism had to negotiate with a composite pre-existing colonial urban setting, which was not possible to ignore or sweep away. 

sudden increase of the European population, contributed in making the urban planning of Asmara even more difficult. In the early 1930s Asmara was still a small town of 18,000 inhabitants, out of which 3,000 (17\%) were Italians. In 1938 the size of Asmara's population had skyrocketed to 98,000 inhabitants and the Italian community had increased dramatically to 53,000 (54\%) (Consociazione Turistica Italiana 1938: 199). This sudden demographic growth reflected the fact that in the colonial perspective, Asmara had changed its political and strategic function and was now, together with the town of Dekamhare, the main operational and logistic headquarter for military activities launched by Fascism against Ethiopia from the so-called Scacchiere nord (the Northern Operational Theatre) (Fornaciari 1937: 23-24; Fossa 1938: 403). Therefore, it was urgent for the fascist regime to accommodate this mass of population, safeguarding, at the same time, criteria of racial prestige by avoiding embarrassing promiscuity between indigenous and Italian populations.

This uneasy task was given to the architect Vittorio Cafiero, sent to Eritrea in June $1938^{43}$ by the Ministero dell'Africa Italiana ${ }^{44}$ (Ministry for Italian Africa) to accommodate this complex urban and social environment. Basically, Cafiero's efforts were aimed at integrating the new districts, sprouted disorderedly in the wake of the invasion of Ethiopia, in the new functional and, at the same time, more segregationist fascist vision of urban space (Amoroso 1939). This was done by reorganising the town of Asmara along the earlier criterion of zone system, now adapted to the mutated demographic context. The result of this effort is depicted clearly in a study of the fascist scholar Mario Amoroso on the reorganisation of the colonial urban space. Amoroso reports of an Asmara divided between 53,000 nazionali (Italians) and 45,000 indigeni (Eritreans). In this highly Italianised Asmara, 3,742,500 square metres were allocated to the Italian population and 1,164,300 square metres to the indigenous one, which account for a density of 140 inhabitants per hectare in the European area and 380 inhabitants per hectare in the Eritrean area (ibid:: $391)^{45}$. Amoroso in his study makes clear that one of the main concerns of fascist urban planners was to counter the current trend toward an uncontrolled expansion of indigenous districts in the market area into European residential areas ${ }^{46}$. To contain this trend, the mixed zone was designed as a filter, a "diaphragm" in the words of the author, in which only the commercial or administrative segment of the Eritrean population would have been in contact with European districts. At the same time the zone reserved to the indigenous population was translated to the north-east in order to insulate it from the European area $^{47}$.

31 However, it has to be emphasised that the implementation of racial bars in Colonial Eritrea both during the Liberal and the Fascist periods was never an easy process as it had to face many contradictions. Various factors concurred to that, among them the poor living conditions of many Italian settlers, which differed little from those of the so-called sudditi coloniali (Taddia 1988: 81). Moreover, many Italians had been living in official or semi-official conjugal relations with Eritrean women for a long time and were not always ready to give up their relationships at the simple request of the fascist authorities ${ }^{48}$.

\section{Ascari and Urbanisation}

32 If a privileged link existed, connecting the composite set of colonial urban strategies and the Eritrean society, it can be identified in the ascari. The second part of this paper will 
demonstrate the centrality of ascari in Italian urban strategies both at a territorial and social level. The first aspect that emerges clearly is that, if little investigation has been done on the history of Eritrean colonial soldiers serving under Italian colonial rule ${ }^{49}$, even fewer efforts have been made in order to assess the role played by Eritrean ascari in the process of urbanisation in Eritrea ${ }^{50}$.

Nevertheless, there is a variety of reasons to justify an attentive and scrupulous investigation of this chapter of Eritrean history. There are figures first of all. Figures are always a sensitive issue for the historian, and this is particularly true in the case of Eritrean ascari. In fact, up to now, in spite of the frequently stated relevance of the recruitment of Eritreans in the colonial army, there are no detailed quantitative studies of this phenomenon and it is extremely difficult to extrapolate precise data from the colonial literature or from archival documents. A case in point is the ambivalent utilisation of the denomination Battaglioni Eritrei (Eritrean Battalions) in the military literature. In fact, often those battalions were not composed exclusively of Eritreans but included soldiers from neighbouring countries, particularly Ethiopia and Sudan. Moreover, after the Italian invasion of Ethiopia of 1935, there was an administrative and territorial reorganisation which substantially expanded Eritrea far beyond its present boundaries, including the whole Tegray and part of Wallo. However, though detailed calculations are still to be made, there are indications which suggest that approximately 130,000 Eritreans served in the Italian colonial army between the years 1890 and 1935 with an apex of roughly 60,000 during the campaign for the invasion of Ethiopia in 1935 (Killion 1998: 91). To fully appreciate the relevance of those figures, it has to be mentioned that the Eritrean population in 1935 was estimated to be around 600,000 (Tekeste Negash 1987: 51). Those figures show clearly that the ascari's phenomenon had a substantial impact, directly or indirectly, on the whole Eritrean society.

The history of ascari goes parallel to the beginning of the Italian colonial expansion in Eritrea. The first official mention of the employment of colonial troops in Eritrea goes back to 24 December 1881, when a small platoon of local troops was organised in Assab with function of police in charge of the enforcement of law and order (Scardigli 1996: 8). However, systematic employment of local soldiers for military purposes started immediately after the occupation of Massawa in 1885. The first batch of troops were recruited among soldiers of sundry nationalities and irregular troops, generically known as bashi-buzuk ${ }^{51}$, which were serving in the Egyptian garrison in Massawa at the moment of the Italian occupation. This first force was put under the command of Aga Osman, a former Albanian officer of the Egyptian garrison in Massawa (Tracchia 1940: 187). In Spring 1887, also as a consequence of the disastrous defeat suffered at Dog'ali, Italian military authorities decided to reorganise this heterogeneous army of roughly 1,000 soldiers to make it more effective, though the main organisational features of the Ottoman army were retained (Vitale 1960: 125).

Generally speaking, the Italian use of colonial troops, in the early period, was marked by inconsistency, mainly due to the lack of complete trust in indigenous troops, which were suspected to defect easily to the enemy at the slightest reverse in combats' fortune (Tracchia 1940: 189). The first important change in attitude appeared in the Royal Decree of 11 December 1892, which included colonial troops in the Royal Italian Army, though with a separate and subaltern status ${ }^{52}$. The Italian attitude toward Eritrean ascari changed further after the military events of the 1890s, and particularly after the battle of Adwa, in 1896, when many Eritrean ascari fell under the fire of Emperor Menelik ${ }^{53}$. 
36 After the Battle of Adwa, Eritrean ascari were not employed in military operations in Eritrea until the invasion of Ethiopia launched by Mussolini in October 1935. During this period Eritrean ascari were dispatched along different colonial fronts, namely, Somalia and Libya. Eritrean troops were repeatedly sent to Somalia in 1896, 1908, 1920, 1925, 1926 and 1927 (Vitale 1960: 133). By the time Italy launched its campaign against Libya in 1911, Eritrean troops were organised into nine battalions, increased to twelve in 1913 and later on to fifteen (ibid.: 135$)^{54}$. The protracted Libyan campaign represented a watershed in the history of Eritrean colonial troops as well as in the social history of Eritrea at large. From a military point of view, the performances of Eritrean ascari during this protracted and bloody campaign dispelled the last Italian doubts about their employability. However, from a social and economic point of view, the drainage of such a substantial amount of manpower from productive activities ${ }^{55}$ affected heavily the Eritrean economy and also introduced elements of tension between colonial authorities in Rome and the colonial administration in Eritrea, the latter being caught between the contrasting needs of supporting military operations in Libya and strengthening the Eritrean economy ${ }^{56}$.

Finally, the most significant employment of Eritrean ascari was in 1935 when the Italian Fascist regime launched a massive offensive to invade Haile Sellase's Ethiopia. To this purpose, Italy raised a huge army of 200,000 soldiers out of which approximately 60,000 were Eritrean colonial soldiers (Badoglio 1937: 249). This campaign had a deep impact on many aspects of the Eritrean society, one of which, as will be discussed later, was definitely urbanisation.

Apart from this quantitative dimension other aspects made the military factor relevant to an analysis of the urbanisation process in Eritrea. The most important one was introduced by the Disposizione Ministeriale (Ministerial Provision) no. 39429 of 20 September 1908, known as Regolamento di disciplina per i militari indigeni del Regio Corpo di truppe Coloniali d'Eritrea (Disciplinary regulations for indigenous soldiers serving in the Royal Corp of Colonial troops of Eritrea). Article 31 of the above-mentioned decree, following an old local military tradition, allowed ascari to be joined by their families during military campaigns and also planned the building of entirely new districts in the growing urban centres which were reserved only to ascari's families, the so-called campifamiglia (family camps) (Mori 1914: Vol. VI 346). To enforce that policy the regulation made clear that those families which would have established their residence outside military camps would have not benefited from housing allowances normally paid to those families residing in the camps, not even the monthly 15 Italian lira usually paid to those families which, for exceptional reasons, had not found an accommodation in the camp. What is striking in the Italian policy of the campi-famiglia is that it went against the prevailing attitude of suspicion toward the establishment of permanent military settlements in urban areas which was common in the metropolitan territory. In fact, in Italy there was the shared fear that the concentration of troops in urban areas, in a period marked by tense social relations, could have created the possibility for insurrectional alliances between working class and soldiers (Del Negro 1989; Davis 1989).

The campi-famiglia's policy, implemented after an initial period of Italian disinterest with regard to accommodation for ascari Wylde (1970: 124), contributed to the sudden growth of urban areas and gave a strong imprint to colonial urban planning in Eritrea. Those military camps, as described in the colonial literature and shown in contemporary iconographic materials, were huge encampments marked by geometrically designed roads ${ }^{57}$. According to the regulations, each family had its own house, which was built with 
bricks and had the roof made with stubble, hay and reed. The design was modelled after the local hut known in Italian sources as tucul ${ }^{58}$. Ascari were expected to build their houses by themselves ${ }^{59}$, under the supervision of Italian officers, and a basic rule was that building materials were to be, as much as possible, locally available ${ }^{60}$.

Finally, ascari and military in general played an important role in reshaping the colonial landscape through their involvement in the construction of infrastructures. In fact, the building of roads and railways was strictly related to the military and, at the same time, was a determining factor in urban growth ${ }^{61}$. Railways in particular were originally conceived mainly for military purposes and their design was heavily affected by the development of military events in the region (Astuto 1943: 161-163). In fact, in the original plans of governors Baratieri (Baratieri 1988: 157), first, and Martini (Martini 1895: Vol. I 608), later, the railway was mainly planned to serve for the quick and effective deployment of troops over the territory (Maggi 1996: 51). Also the first aeronautical infrastructures in Eritrea were built in the 1920s for military purposes and employing military manpower (Vitale 1960: 158-159). The first two airports were built in Massawa and Asmara in 1920 and, later on, others were opened in Keren, Agordat, Barentu and Thi'o (ibid.). This effort for the development of colonial infrastructures had a further boost when Fascist Italy started the preparation for the invasion of Ethiopia. To expedite the movement of people and goods, an impressive network of roads was also laid down and completed at an extremely fast pace $^{62}$.

\section{Toponymy}

41 A further evidence of the relevance of the military in the urban history of colonial Eritrea is also attested by toponymy. The few existing studies on Eritrean toponyms focus mainly on pre-colonial period and, unfortunately, deal only with Tigrinya speaking areas (Conti Rossini 1938; Franchini 1983). However, a quick survey provides enough evidence of the colonial and military origin of many Eritrean villages and districts.

One of the most recurrent toponyms is Forto, the Eritrean corruption of the Italian forte, which stands for fort or military fortification. Almost all urban centres grown up during colonial time have their own Forto, which, actually, was the pivotal structure around which those centres expanded. That is the case of Agordat, Barentu, Keren ${ }^{63}$, Mendefera ${ }^{64}$ and Saganeiti. Some villages are simply named Forto and still bear evidences of military fortifications, built mainly on hilly or mountainous locations. This is the case, for example, of the homonymous village close to the town of Zalambessa on the border with Ethiopia. In Asmara there are places, like Forto Baldissera ${ }^{65}$ (former Fort Bet Makha'e) or Amba $^{66}$ Galliano $^{67}$ (Mount Galliano) that had, and in some cases still have, their name associated to those of Italian officers active in Eritrea.

Another frequent toponym used to denominate urban districts in Eritrea is Gheza Banda which could be translated, literally, as "House of the Band". Bandas were irregular troops recruited on a local basis and often under the command of a local chief. Those Banda were employed by the Italians beside regular troops and were mainly used for activities of territorial police or for unconventional warfare (Tracchia 1940: 188). Those units were employed particularly during the fascist invasion of Ethiopia to fight the Ethiopian resistance ${ }^{68}$. Normally those Gheza Bandas indicate districts originally inhabited by those colonial troops and could be found, for instance, in Asmara and Keren. In Asmara there are two Gheza Banda, the first one is known as Gheza Banda Habasha ${ }^{69}$ (house of the 
Abyssinian Banda) and refers to a district originally inhabited by colonial irregular troops. The second one is known as Gheza Banda Telian (House of the Italian Banda). This refers to the fact that this district was originally inhabited by local troops that were later evicted and moved to the area known as Gheza Banda Habasha to make room for Italian troops (Onnis 1957: 137) ${ }^{70}$. Another interesting example of the relevance of toponymy is the locality of Addi Telleria, which is the result of the combination of the Tigrinya word Addi, which means village, and Telleria, the Tigrinya corruption for the Italian artiglieria corresponding to the English artillery. This testifies of areas originally assigned to artillery batteries or to troops manning artillery (Amanuel Sahle 1984).

In the town of Asmara there are still many other areas whose origin could be traced back to their military function. The most important, for example, is the downtown district known as Kommishtato, Tigrinya corruption for the Italian Campo cintato (enclosed camp). A popular Eritrean belief attributes the origin of this name to segregationist policies introduced by the Fascist regime in Eritrea in 1938. The etymology of the toponym Kommishtato would refer to the fascist decision to fence a residential area prevalently inhabited by Europeans, and make it inaccessible to Eritreans. However, the real origin of this name goes back to the earliest phase of the Italian occupation of Asmara. That area was in fact confiscated by General A. Baldissera in 1889 and transformed into a key military operational centre from where the Italian Army co-ordinated its occupation of the southern highlands of Eritrea (Baldissera 1897: 13; Zoppi 1935). Therefore, at this stage, its being fenced was inspired mainly by security reasons rather than by segregationist policies.

Another example of toponym related to the military is the district of Asmara known as Deposito (the Italian for warehouse) or Deposito invalidi (disabled's warehouse). It refers to an area where there were military warehouses (Deposito), later on transformed into residences for disabled veterans (invalidi) or retired colonial troops. In the same way, the district of Villaggio Genio (Village of the Genio) refers to an area originally assigned to troops from the Engineers Corps (Genio in Italian), normally in charge of building and maintaining military infrastructures. Another example of urban settlement associated with the military is the so-called Villaggio Azzurro (Blue Village), which represents an interesting case of historical continuity. In fact, Villaggio Azzurro was built in the 1930s by fascists as a reward to decorated Eritrean war veterans and their families (Amoroso 1939: 393). Villaggio Azzurro takes its name from the blue colour of the ribbon used in the Italian army to attach military decorations and which, in the Italian tradition, was also both the symbol of military bravery and of the Savoia royal family ${ }^{71}$. A peculiarity of this district is the fact that it was a development of a military camp established in the area at the early stage of Italian colonialism, known as Campo Galliano, from the name of general Galliano (Paoli 1908: 57). Interestingly enough in the same area, later on, the Ethiopian military regime of the Derg built a residential camp for Eritrean soldiers enrolled in the elite corps known as commandos which was popularly named Campo Kunama, after the name of the ethnic group which was prevalently settled in that camp.

Similarly the two districts of Tabba, originally also known as Tabba Generali and Tabba Geltemtem, refer to areas where military convoys used to stop in order to rest and change their exhausted quadrupeds for fresh ones (Yshaq Yosef 1993: 35). In fact, Tabba is the local corruption of the Italian tappa, which literally means "stopping place" and in the military jargon referred to a place where soldiers could change their horses, leave or fix their carriage, and get food. The now disused toponym May Botoloni ${ }^{72}$ (Waters of the 
Battalion) refers to an area in old Asmara where there was a river used by colonial troops to water their horses and mules. In fact Botoloni (Amanuel Sahle 1984: 84) is the Tigrinya corrupted version for the Italian battaglione which means battalion (Yshaq Yosef 1993: 35). Finally another interesting example of toponym related to the military is the name of Haddish Addi (New Village), given both to a district in Asmara and to one in Mandefera. In the Tigrinya-speaking highlands of both Eritrea and Tegray, the name Haddish Addi indicates villages which were originated by migrations or displacement of a group from its original settlement (Conti Rossini 1938: 806). In the case of Eritrea, often, this name indicates military origins, as it bears evidence of the migration towards Eritrea of peoples from the Ethiopian regions of Tegray and Gojjam, looking for job opportunities and particularly for recruitment in the Italian colonial army. In this case, the name Haddish Addi testifies of an area given by the colonial authority to exogenous communities, through exceptional procedures of landallocation. By so doing the colonial administration circumvented the otherwise strict regulations of customary laws which, even in urban centres, allocated land to the original inhabitants through a complex system of inheritance (Conti Rossini 1916: 148).

\section{Social Consequences of the Military on Urbanisation}

In Eritrea the process of urban growth related to the settlement of colonial troops is also important for its economic and social implications. Apart from the human costs of this process in terms of forced dislocation of indigenous communities from their ancestral land, as in the case of Bet Makha'e, this process is also crucial for an understanding of some structural transformations of Eritrean society during the colonial period. From an economic point of view it has to be stressed that ascari as a social category were de facto a sort of elite, due to their pay which, particularly during military campaigns, was definitely beyond the average wages that Eritreans could earn in the colonial labour market (Vitale 1960: 101-102). As already mentioned this prompted serious imbalances in the Eritrean labour market. On one side it created a shortage in the availability of manpower for productive activities particularly in agriculture. Indicative of this situation are figures reported by G. Simonini (1940 quoted in Tekeste Negash 1987: 51), who in a very interesting study mentioned the dramatic shortage of manpower in the region of Särae where, out of a population of 111,664 inhabitants only 21,909 were gäbbar ${ }^{73}$ (farmers) when approximately 25,000 were recruited as ascari. The impact of this trend on colonial economy is demonstrated also by the fact that Colonial authorities were forced to introduce legislative measures aimed at encouraging the migration of manpower from neighbouring countries ${ }^{74}$ and at the same time curb wages in order to contain inflation (Guidotti \& Gubellini 1936). This trend, beside affecting substantially the agricultural sector, also led to a reconfiguration of labour composition in Eritrea by stimulating a massive flux of immigrants from the destitute region of Tigray, ravaged by internecine conflicts and political instability (McCann 1985; Gebru Tareke 1996: 85-87). A further result of this process was also an increased involvement of women in agricultural production though they were still employed mainly in the framework of traditional agriculture (Taddia 1986: 258).

With regard to the urban factor, the massive enrolment of ascari had a significant impact on the development of urban centres, not only in quantitative but also in qualitative terms. In the racially-inspired urban planning of Italian colonialism, ascari were 
perceived as privileged actors acting as a sort of filter, or buffer, between European and indigenous districts. This function of buffer was at the same time physical and social. In fact, in the colonial urban planning special attention was given to ascari and their families (Amoroso 1939: 393) ${ }^{75}$, whose "loyalty" to the colonial administration was rewarded with the allocation of land or housing facilities in urban areas ${ }^{76}$. The above-mentioned area known as Villaggio Azzurro is a case in point. It is interesting to note that in many cases those areas assigned to ascari were in the so-called mixed zone bordering the European zone. From this point of view it is possible to affirm that in colonial urban planning, districts inhabited by ascari were conceived as cultural and physical buffers between European and indigenous districts (Onnis 1957: 165).

However, in the colonial town ascari were given a more complex social role as they were expected to act as a social filter between colonial administration and colonial subjects. This was to be achieved through a complex and gradual process of co-optation of ascari in the colonial apparatus, which started from the very first stage, their recruitment. In fact, in the recruitment priority was given to married candidates, and this for two main reasons ${ }^{77}$. Married soldiers were expected to be more reliable, as family responsibilities would have kept them bound to respect their term of service and even renew it, thus providing the colonial army with a precious nucleus of senior and experienced soldiers. Moreover, the colonial administration looked at ascari's families as an important element in the process of construction of the colonial subject. Particular attention was given to ascari's children, which, due to their early and constant contact with the colonial administration were expected to grow loyal and dedicated to the colonial cause (Vitale 1960: 119). This is a pattern which can be observed at the very early stages of Italian colonial rule. An example of this is reported in Renato Paoli's memoirs where he mentions the case of the former Fortino Vigano, located at the entrance of Asmara from the Massawa road. Paoli (1908: 55) reports that this former fort had been converted to a training centre for Eritrean scium-basci-a sort of non-commissioned officers-and that their families lived in the compound, where ascari's children, also mentioned as diavoletti ${ }^{78}$ , were the object of special attention on the side of Italian officers.

In this process of construction of ascari and their families as colonial subjects and privileged social actors, a special role was attributed to language policies. In fact, since the earliest period of Italian colonial rule over Eritrea, a particular emphasis was given to the teaching of the Italian language to colonial troops. Already in 1892 General Baratieri, then military governor of Eritrea, theorised the necessity of building and consolidating loyalty among ascari and their families through both the teaching of Italian and the free allocation of land (Baratieri 1988: 146). This policy was reiterated and clearly stated in the Disciplinary regulations for indigenous soldiers approved in 1908, which in Article 14 envisaged the necessity of teaching Italian to all ascari, thus establishing the command of this language as one of the main prerequisites for the eligibility to promotion (Mori 1914: Vol. VI 333). From those regulations it is possible to infer that, in the colonial strategy, the so-called campi famiglia were expected to be islands of Italianised Eritreans, mediating spatially and socially between the colonial authority and the rest of colonial subjects.

51 However, the final stage of this process of co-optation of ascari in the colonial apparatus was achieved through promotions, and the recruitment in the lower level of colonial civil service after their retirement from the army. Promotions were given to colonial soldiers on the basis of their military merit and of years of service. They consisted of decoration 
with special medals, concession of gun licences, and attribution of honorific titles borrowed from the local military tradition (Vitale 1960: 109) ${ }^{79}$.

Honorific titles like Saleqqa ${ }^{80}$, Balambaras ${ }^{81}$, 'Ona ${ }^{82}$, Grazmacc $^{83}$, and Fitawrari ${ }^{84}$ were awarded during very formal ceremonies in Asmara, normally held in the presence of the Governor of the colony, and usually in coincidence with the celebration of the festivities of Mäsqül ${ }^{85}$ for Christians and 'Eid el Fetr for Muslims ${ }^{86}$. Decorations and promotions operated mainly at the level of the symbolism of power. However, a much more direct, and socially effective praxis of co-optation, was the recruitment of retired ascari in the colonial administration, where a variety of positions, ranging from interpreters, telephone and telegraph operators, to administrative clerks, were reserved to colonial subjects ${ }^{87}$.

This wide spectrum of social and administrative involvement in the colonial administration made the ascari the nucleus of an urban elite whose role in the development of Eritrean nationalism has still to be fully investigated ${ }^{88}$. It is in fact apparent that ascari's massive employment in different fronts had a significant impact in their perception of religious, ethnic, and racial identities. Serving under the same flag, though being from different linguistic, religious and ethnic communities, they played an important role in smoothing, at least partially, consolidated localism and ethnic-based antagonisms, and paved the way for the development of a germinal Eritrean nationalist feeling ${ }^{89}$. Colonial urban policies, through the key mediation of ascari, played a further important role in the re-definition of ethnic, religious and national identities. At the same time, as mentioned earlier, those policies substantially influenced patterns of migration from neighbouring regions.

54 A precious instrument to understand those developments is the military documentation and particularly military regulations implemented by the Colonial army. In fact, those regulations used to put a lot of emphasis on the respect of the Italian flag ${ }^{90}$ as the main aspect in the definition of loyalty and allegiance. At the same time, religious, ethnic or regional identities, though respected and, to a certain extent, also used as criteria in the organisation of the army, tended to be confined to the sphere of private matters ${ }^{91}$. In fact ultimately those regulations tended to inculcate loyalty to platoons, battalions and divisions as the main factor for the development of solidarity and cohesion among colonial troops ${ }^{92}$.

Analysing the role of the military factor in the pre-colonial urban history of Ibadan, Ruth Watson (1999) states that "warfare generated an idea of political community. On the battlefield, warriors led their soldiers on the name of Ibadan". Similarly, also with regard to colonial Eritrea, it can be affirmed that "warfare generated an idea of political community" though in this case the model of political community was suggested by an exogenous force, the colonial authority and ascari were led on the battlefield in the name of Italy. Nevertheless, though still little explored, this remains an important part of Eritrean history, crucial for an in-depth understanding of some of the roots of Eritrean nationalism.

In the light of what I have just exposed, it appears that the military factor played a crucial role in the urban history of colonial Eritrea. Therefore, the study of military urbanisation provides the analytical tools necessary for a correct assessment of Eritrean urban history and, generally speaking, for a better understanding of the Eritrean colonial milieu. The role of the military was crucial in reshaping both the physical and social landscapes of colonial Eritrea. In fact, on one side the military factor dictated priorities in the 
development of early colonial urban settlements and, on the other side the military was also crucial in determining the social and political make-up of the colonised society. In this process the centrality of Eritrean colonial ascari is apparent because of both the quantitative and qualitative dimension of their involvement. Finally the involvement of Eritrean ascari in the urbanisation process also bears heavy consequences for the development of Eritrean post-colonial society.

To this regard, colonial literature provides ample evidence of a policy of co-optation aimed at transforming colonial troops into privileged social actors destined to mediate between colonised and colonisers. In this process of construction of the colonial subject, urbanisation played a very important role. In fact, the urban space can be represented as the ideal social laboratory of colonialism, where ethnic, regional or national identities were moulded, renegotiated and finally redefined. Urbanised ascari were, again, central in this process of redefinition of identities as they were more exposed to colonial culture and also because part of their military training and discipline was specifically aimed at interiorising those new identities. As a result of this long and composite process, urbanised ascari can also be identified as a core component of the germinal Eritrean urban elite.

\section{BIBLIOGRAPHY}

ABIR, M.

1966 "Salt Trade and Politics in Ethiopia in the Zamana Mesafint", Journal of Ethiopian Studies, 2:

$1-10$.

1968 Ethiopia, the Era of the Princes (New York-Washington: Praeser).

AdHANA MENGSTEAB

1990 “The Occupation of Keren by the Egyptians, 4 July 1972-10 April 1885”, in R. PANKHURST, A HMED ZEKARIA \& TADESSE BEYENE (eds.), Kasa and Kasa: Papers on the Lives, Times and Images of Téwodros II and Yohannes IV (Addis Ababa: IES): 367-371.

AJAYI, J. F. Ade

1968 “The Continuity of African Institutions under Colonialism”, in T. O. RANGER (ed.), Emerging Themes in African History: Proceedings of the International Historical Conference held at Dar es Salaam, 1965 (Nairobi: East African Literature Bureau): 189-200.

1981 "Colonialism: An Episode in African History", in L. H. GANN \& P. DuIGNAN, Colonialism in Africa, 1870-1960, vol. 1 (London: Cambridge University Press): 497-509.

ALEMSEGHED ABBAY

1998 Identity Jilted or Re-imagining Identity? (Lawrenceville-Asmara: Red Sea Press).

AmANuel SAHLE

1984 “Tigrigna: Recent History and Development", in Sven RuBENSON (ed.), Proceedings of the Seventh International Conference of Ethiopian Studies (Addis Ababa: IES; Uppsala: NAI; East Lansing: Michigan State University): 79-90.

1988 “A Brief Historical Survey of the Ethiopian Askaris (Native Colonial Soldiers)", in TADESSE B 
EYENE (ed.), Proceedings of the Eighth International Conference of Ethiopian Studies (Addis Ababa: IES):

253-262.

AMORoso, M.

1939 “Le opere pubbliche: I piani regolatori", Gli Annali dell'Africa Italiana, 2 (4): 365-435.

ANDERSON, D. M. \& RATHBONE, R. (eds.)

2000 Africa's Urban Past (Oxford: James Currey).

ANFRAY, F.

1974 "Deux villes axoumites: Adulis et Matara", in Atti del IV Congresso Internazionale di Studi Etiopici - Roma 1972 (Roma: Accademia Nazonale dei Lincei): 745-765.

APOLLONIO, F.

1993 "L'architettura del cannone: occupazione e opere di fortificazione", in G. GRESLERI, P. G. M ASSARETTI \& S. ZAGNONI (eds.), Architettura italiana d'oltremare, 1870-1940 (Venezia: Marsilio):

127-143.

AQUARONE, A.

1989 Dopo Adua: politica e amministrazione coloniale, ed. by L. De COURTEN (Roma: Min. Beni Ambientali e Culturali).

ARCANGELI, A.

1936 La camionale Mar Rosso-altipiano Eritreo: Massaua, Nefasit, Decameré (Roma: Istituto Grafico Tiberino).

ARKEIL, A. J.

1954 "Four Occupation Sites at Agordat", Kush, Journal of the Sudan Antiquity Service, 2 (33-42).

AstuTo, R.

1943 Il problema ferroviario dell'Africa (ISPI: Milano).

Ayele TEKLE-HAYMANOT

1965 “Le antiche gerarchie dell'Impero Etiopico", Sestante, 1 (2): 61-67.

BADOGLIO, P.

1937 La guerra d'Etiopia (Milano: Mondadori).

BAIRU TAFLA

1994 "Interdependence through Independence: The Challenges of Eritrean Historiography", in H. MARcus (ed.), New Trends in Ethiopian Studies, Papers of the $12^{\text {th }}$ International Conference of Ethiopian Studies, Michigan State University, 5-10 September (Lawrenceville: Red Sea Press): 497-514.

BALDISSERA, A

1897 Relazione sulla occupazione dell'Asmara (Roma: Sonzogno).

BARATIERI, O.

1988 Memorie d'Africa (1892-1896) (Genova: F. lli Melita).

BARRERA, G.

1996 Dangerous Liaisons: Colonial Concubinage in Eritrea, 1890-1941, PAS Working Paper, 1

(Evanstone, Ill.: Northwestern University).

BATTAGLINI, G.

1938 Con S.E. De Bono: nel turbinio di una preparazione (Roma: Airoldi).

BEREKETEAB REDIE

2000 Eritrea: The Making of a Nation (Uppsala: Uppsala University). 
BERKELEY, G. F. H.

1969 [1902] The Campaign of Adowa and the Rise of Menelik (New York, Negro University Press).

Bizzoni, A.

1897 L'Eritrea nel passato e nel presente (Milano: Sonzogno).

BORALEVI, A.

1986 “Le 'città dell'Impero': urbanistica fascista in Etiopia, 1936-1941”, in A. MioNi (ed.),

Urbanistica fascista. Ricerche e saggi sulle città e il territorio e sulle politiche urbane in Italia tra le due guerre (Milano: Franco Angeli).

Bosio, G.

1937 “Future città dell'Impero", Architettura, 16 (2): 419-431.

BURTON, A.

2001-2002 "Proceedings of the workshop on 'Urbanism in Eastern Africa”, Azania, 36-37.

BUTZER, K. W.

1981 "Rise and Fall of Axum, Ethiopia: A Geo-Archaeological Interpretation", American Antiquity, 40: 471-495.

CAMPASSI, G.

1987 "Il madamato in Africa Orientale: relazioni tra italiani e indigene come forma di aggressione coloniale", Miscellanea di storia delle esplorazioni.

CARDOZA, A. L.

1989 "An Officer and a Gentleman: the Piedmontese Nobility and the Military in Liberal Italy", in Esercito e città dall'Unità agli anni 30. Atti del convegno di studi, Perugia 11-14 maggio 1988 (Roma: Ministero per i Beni Culturali e Ambientali): 185-199.

CAROCCI, G.

1969 La politica estera dell'Italia Fascista (1925-1928) (Bari: Laterza).

CASTI MORESCHI, E.

1998 "Nomi e segni per l'Africa italiana: la carta geografica nel progetto coloniale", Terra d'Africa, 7: 13-60.

CATTANEO, A.

1935 La città considerata come principio ideale delle istorie italiane (Firenze: Vallecchi).

CAULK, R. A.

1971 "Yohannes IV the Mahdist, and the Colonial Partition of North-East Africa", Transafrican Journal of History, 1 (2): 23-41.

1978 “Armies as Predators: Soldiers and Peasants in Ethiopia (ca. 1850-1935)”, International Journal of African Historical Studies, 3 (11): 457-497.

1984 "Bad Men of the Borders: Shum and Shefta in Northern Ethiopia in the Nineteenth Century”, International Journal of African Historical Studies, 17 (2): 201-227.

1986 “'Black Snake, White Snake': Bahta Hagos and His Revolt against Italian Overrule in Eritrea, 1894", in D. CRUMmeY (ed.), Banditry, Rebellion, and Social Protest in Africa (London: James Currey): 293-309.

ChAudhuri, K. N.

1985 Trade and Civilisation in the Indian Ocean (Cambridge: Cambridge University Press). 
CIUCCI, G.

1993 "Architettura e urbanistica. immagine mediterranea e funzione imperiale", in G. GRESLERI, P. G. MASSARETTI \& S. ZAGNONI (eds.), Architettura italiana d'oltremare (Venezia: Marsilio): 109-115.

COBOLLI GIGLI, G.

1938 Strade imperiali (Milano: Mondadori).

1941 Strade romane in Dancalia (Roma: Ricci).

Collotti, E., Labanca, N. \& Sala, T.

2000 Fascismo e politica di potenza. Politica estera, 1922-1939 (Firenze: La Nuova Italia).

CONSOCIAZIONE TURISTICA ITALIANA

1938 Africa Orientale Italiana Guida d'Italia della Consociazione Turistica Italiana (Milano: CTI).

Conti Rossini, C.

1903 "Documenti per l'archeologia eritrea nella bassa valle del Barca", Rendiconti della

R. Accademia dei Lincei. Classe di scienze Morali Storiche e filologiche, serie V, vol. XII: 139-150.

1904 "I Loggo e la legge dei Loggo Sardà", Giornale della Società Asiatica Italiana, 17: 1-63.

1906 “Sugli Habasât”, Rendiconti dellla Re. Accademica dei Lincei, 15: 39-59.

1916 Principi di diritto consuetudinario dell'Eritrea (Roma: Tipografia dell' Unione).

1922 “Antiche rovine sulle Rore eritree (Strabone, XVI, 8; Plinio, VI, 191)", Rendiconti della

R. Accademia dei Lincei. Classe di scienze Morali Storiche e filologiche, serie V, vol. XXXI: 241-278.

1928 Storia d'Etiopia (Milano: Bergamo).

1938 "Saggio sulla toponomastica dell'Eritrea tigrina", Bollettino della R. Società Geografica Italiana, vol. LXXV, serie VII, vol. III, n. 10: 785-816.

COQUERY-VIDROVITCH, C.

1992 Histoire des villes africaines des origines à la veille de la colonisation (Paris: Payot).

CRUMmeY, D.

1986 "Noble and Peasant: Banditry and Resistance in Nineteenth-Century Ethiopia", in D. C RUMMEY (ed.), Banditry Rebellion, and Social Protest in Africa (Oxford: James Currey).

CURTIS, M. C. \& YOSEF LIBSEKAL

1997 “Archaeological Survey in the Adi Qeyeh Area”, Nyame Akuma, 51: 25-35.

DAVIS, J. A.

1989 “The Army and Public Order in Italian Cities", in Esercito e città dall'Unità agli anni 30. Atti del convegno di studi, Perugia 11-14 maggio 1988 (Roma: Ministero per i Beni Culturali e Ambientali): 483-498.

De Almeida, M.

1954 "The History of High Ethiopia or Abassia", in C. F. BECKINGHAM \& G. W. B. HunTINGFORD (trans. and eds.), Some Records of Ethiopia (London: Hakluyt Society).

Del Boca, A.

1976-1984 Gli italiani in Africa Orientale (Bari: Laterza).

Del Negro, P.

1988 “La professione militare nel Piemonte costituzionale e nell'Italia liberale", in G. N CAFRIO and P. Del Negro (eds.), Ufficiali e società (Milano: Franco Angeli): 211-230.

1989 "Caserma e città nel discorso militare dell'Italia liberale", in Esercito e città dall'Unità agli anni 30. Atti del convegno di studi, Perugia 11-14 maggio 1988 (Roma: Ministero per i Beni Culturali e Ambientali): 149-168. 
Denison, E., ReN, G. Y. \& NAIZGHi GeBREMEDhin

1986 "The Unity and Territorial Integrity of Ethiopia", The Journal of Modern African Studies, 24

(3): 467-487.

2003 Asmara - Africa's Secret Modernist City (London: Merrell Publishers).

Di NoLfo, E.

1966 Mussolini e la politica estera italiana del fascismo, 1919-1933 (Padova: CEDAM).

FATTOVICH, R.

1988 "Remarks on the Late Prehistory and Early History of Northern Ethiopia", in TADESSE B EYENE (ed.), Proceedings of the VIII International Conference of Ethiopian Studies (IES: Addis Ababa): 85-93.

FAZI, L.

1968 I guerriglieri del mal d'Africa (Roma: I libri del No).

FERNYHOUGH, T.

1986 "Social Mobility and Dissident Elites in Northern Ethiopia: The Role of Bandits, 1900-1969", in D. CRUMmeY (ed.), Banditry Rebellion, and Social Protest in Africa (Oxford: James Currey): 151-172.

FERRARI, A.

1940 Con i barbari contro i barbari (Napoli: Ruspoli).

FORNACIARI, J.

1937 Nel piano dell'Impero (Bologna: Cappelli).

FossA, D.

1938 Lavoro italiano nell'Impero (Milano: Mondadori).

FRANCHINI, V.

1983 “Contributo alla toponomastica dell'Eritrea tigrina", Quaderni di studi etiopici, 3-4: 163-175.

FULLER, M.

1991 "Edilizia e potere; l'urbanistica e l'architettura coloniale italiana", Studi piacentini, 9:

117-155.

1996 "Wherever You Go, There You Are: Fascist Plans for the Colonial City of Addis Ababa and the Colonizing Suburb of Eur'42", Journal of Contemporary History, 31: 397-418.

GAMBI, L.

1994 “Geography and Imperialism in Italy: from the Unity to the 'New' Roman Empire", in A. G oDLEWSKA \& N. SMITH (eds.), Geography and Empire (Oxford: Blackwell): 74-91.

GANN, L. H. \& DUIGNAN, P.

1967 Burden of Empire (London: Pall Mall).

GEBRU TAREKE

1996 [1991] Ethiopia, Power and Protest (Lawrenceville NJ: Red Sea Press).

GETACHEW HAILE

1986 "The Unity and Territorial Integrity of Ethiopia", The Journal of Modern African Studies, 24 (3): 467-487.

GOGLIA, L.

1985 "Una diversa politica razziale coloniale in un documento inedito di Alberto Pollera del 1937", Storia Contemporanea, 11 (5-6).

1992 "Sul razzismo coloniale italiano", Materiali di lavoro, 2-3 (1991), 1 (1992): 97-115.

1998 Colonialismo e fotografia: il caso italiano (Messina: Sicania). 
GogLiA, L. \& GRASSI, F.

1981 Il colonialismo italiano da Adua all'impero (Roma-Bari: Laterza).

Gooch, J.

1989 Army, State and Society in Italy, 1870-1915 (London: McMillan).

GResLeri, G., MASSARETTI, P. G. \& ZAGNONI, S. (eds.)

1993 Architettura italiana d'oltremare, 1870-1940 (Venezia: Marsilio).

GUidi, I. \& VALLE, C.

1937 “Programma urbanistico per Addis Abeba", Architettura, 16 (2): 755-768.

GuidotTI, R. \& GUBELLINI, M.

1936 "Il problema dei salari della mano d'opera di colore in Eritrea nel periodo pre e postbellico", L'agricoltura coloniale, 12 (30): 441-450.

HENZE, P.

2000 Layers of Time (London: Hurst \& Company).

HoBSBAWM, E. J.

1969 Bandits (London: Weidenfeld \& Nicolas).

HoPKINS, A. G.

1973 An Economic History of West Africa (London: Longman).

HORVATH, R. J.

1969 “The Wandering Capitals of Ethiopia”, Journal of African History, X (2): 205-219.

HUSSEIN AHMED

1985 Clerics, Traders and Chiefs: A Historical Study of Islam in Wallo (Ethiopia) with Special Emphasis on the Nineteenth Century, Ph.D Thesis, University of Birmingham.

2001 Islam in Nineteenth-Century Wallo, Ethiopia: Revival, Reform and Reaction (Leiden: E.J. Brill).

JORDAN GEBRE-MEDHIN

1989 Peasants and Nationalism in Eritrea (Trenton: Red Sea Press).

KILLION, T.

1998 Historical Dictionary of Eritrea (Landham-London: Scarecrow Press).

KING, D.

1976 Colonial Urban Development: Culture, Social Power and Environment (London: Routledge \& Kegan Paul).

LABANCA, N.

1999 "Il razzismo coloniale italiano", in A. BURGIo (ed.), Nel nome della razza: il razzismo nella storia d'Italia, 1870-1945 (Bologna: il Mulino): 145-164.

LE Huerou, F.

1994 L'épopée des soldats de Mussolini en Abyssinie (1936-1938): les “Ensablés” (Paris: L’Harmattan).

1999 "Les ascari érythréens créateurs de frontières", Vingtième siècle, 63 (juillet-septembre):

17-22.

LOBO, J.

1735 A Voyage to Abyssinia, translated by S. Johnson (London).

MAGGI, S.

1996 Colonialismo e Comunicazioni: Le strade ferrate nell'Africa italiana (Napoli: Edizioni Scientifiche Italiane). 
MAIONE, G.

1979 L'imperialismo straccione (Bologna, il Mulino).

MARINUCCI, C.

1963 L'Italia in Africa. Il governo dei territori d'oltremare: Parte I Gli organi centrali (Roma: Istituto Poligrafico dello Stato).

MARTINI, F.

1895 Nell'Affrica italiana (Milano: Treves).

MC CANN, J.

1985 "The Political Economy of Rural Rebellion in Ethiopia: Northern Resistance to Imperial Expansion, 1928-1935”, International Journal of African Historical Studies, 18 (4): 601-623.

MIEGE, J. L.

1976 L'imperialismo coloniale italiano dal 1870 ai giorni nostri (Milano: Rizzoli).

MigneMI, A.

1988 “Modelli visivi per un impero", AFT-Archivio Fotografico Toscano, 6 (8): 62-67.

Mioni, A.

1980 Urbanistica fascista. Ricerche e saggi sulle città e il territorio e sulle politiche urbane in Italia tra le due guerre (Milano: Franco Angeli).

MiRAN, J.

2004 [Forthcoming] "Islamic Court Records from Nineteenth-Century Massawa: A Source for Social and Economic History” in O. Beraki, Uoldelul Chelati Dirar \& Yemane MesGhenna (eds.), Independent Eritrea: Lessons and Prospects. Proceedings of the First International Conference of Eritrean Studies (Asmara: ESA), 2003.

MORI, A.

1914 Manuale di legislazione della Colonia Eritrea, 7 vol. (Roma: L'Universelle).

MUNRO-HAY, S.

1991 Aksum: an African Civilisation of Late Antiquity (Edinburgh: Edinburgh University Press).

MunRo-HAY, S. \& TRINGALI, G.

1993 "The Ona Sites of Asmara and Hamasen", Rassegna di Studi Etiopici, 35: 135-170.

ODORIZZI, D.

1911 Il Commissariato Regionale di Massawa al 1ํ Gennaio 1910 (Asmara: Fioretti).

OLIVER, R. \& ATMORE, A.

1972 Africa since 1800, $2^{\text {nd }}$ ed. (Cambridge: Cambridge University Press).

ONNIS, E.

1957 La città di Asmara, B.A. Thesis, Padova.

PANKHURST, R.

1968 Economic History of Ethiopia, 1800-1935 (Addis Ababa: Addis Ababa University).

1971 “Italian and 'Native' Labour during the Italian Fascist Occupation of Ethiopia, 1935-1941", paper presented at the Conference on Innovation in African Economic history, University of Ghana, Legon, 14-20 December.

1982 History of Ethiopian Towns, 2 vols. (Wiesbaden: Franz Steiner).

1984 "Ethiopian Taxation Prior to the Time of Menilek: A Collation and Analysis of Estimates, Part I", Northeast African Studies, 3: 59-82.

1985 The History of Famine and Epidemic in Ethiopia Prior to the Twentieth Century (Addis Ababa: 
$\mathrm{RRC})$.

2002 "Across the Red Sea and the Golf of Aden: Ethiopia's Historic Ties with Yaman", Africa, 15 (3): 393-419.

PAOLI, R.

1908 Nella Colonia Eritrea (Milano: Fratelli Treves).

PARTINI, R.

1938 “Architetture autoctone nell'Africa Orientale italiana", Architettura, 17 (5): 261-270.

PATASSini, D.

1993 "Compiacenza e estraniazione nei piani urbanistici di Addis Abeba dalla fondazione al 1890", in C. DiAMANTINI \& D. PATASSINI, Addis Abeba: villaggio e capitale di un continente (Milano: Franco Angeli): 187-292.

PERINI, R.

1905 Di qua dal Mareb (Mareb Mellash) (Firenze: Tipografia Cooperativa).

PianAVIA-VIVALDI, R.

1901 Tre anni in Eritrea (Milano: Cogliati).

PINI, C. G.

1912 Frammenti dei miei ricordi d'Affrica (Città di Castello: Lapi).

Poggiali, C.

1971 Diario AOI (Milano: Longanesi).

Pollera, A.

1913 Il regime della proprietà terriera in Etiopia e nella colonia Eritrea (Roma: Ministero delle Colonie).

1926 Lo Stato etiopico e la sua Chiesa (Milano: SEAI).

1935 Le popolazioni indigene dell'Eritrea (Bologna: Cappelli).

Puglisi, G.

1953 Chi è dell'Eritrea (Asmara: Tipografia Regina).

RABINOW, P.

1989 French Modern Norms and Forms of the Social Environment (Cambridge, MA: MIT Press).

RAINERO, R.

1960 I primi tentativi di colonizzazione agricola e di popolamento dell'Eritrea (1890-1895) (Milano: Marzorati).

RASTER, D. N.

1973 “The Colonial District Town in Uganda”, in E. P. BECKInSALE \& J. M. Houston (eds.), Urbanisation and its Problems (Oxford: Blackwell).

RAVA, C. E.

1938 “Architettura Coloniale”, Gli Annali dell'Africa italiana, 1 (3-4): 1293-1300.

Risso, P.

1995 Merchants and Faith: Muslim Commerce and Culture in the Indian Ocean (Boulder: Westview Press).

RossinI, G.

1989 Biografie italo-africane, n.p. 
RUBENSON, S.

1976 The Survival of Ethiopian Independence (London: Heinemann).

RUTH IYoB

1995 Eritrean Struggle for Independence (Cambridge: Cambridge University Press).

2000 "Madamismo and beyond. The Construction of Eritrean Women", Nineteenth-century contexts.

SCARDIGLI, M.

1996 Il braccio indigeno (Milano: Franco Angeli).

SCHMIDT, P. \& CURTIS, M. C.

2001 "Urban Precursors in the Horn: Early $1^{\text {st }}$ Millennium BC Communities in Eritrea", Antiquity, 75: 849-859.

SHIFERAW BEKELE

1990 “The State in Zamana Masafent (1786-1853): An Essay in Reinterpretation", in TADESSE B eyene, R. PANKhURST \& ShIFERAW BeKELE (eds.), Kasa and Kasa: Papers on the Lives, Times and Images of Téwodros II and Yohannes IV (Addis Ababa: IES): 25-68.

SIMONINI, G.

1940 “La regione del Serae", Gli Annali dell'Africa Italiana, 3 (3): 81-134.

SORGONI, B.

1998 Parole e Corpi (Napoli: Liguori).

TADESSE BEYENE (ed.)

1990 Proceeding of the First National Conference of Ethiopian Studies (Addis Ababa: IES): 367-381.

TADDIA, I

1985 "Intervento pubblico e capitale privato nella Colonia Eritrea", Rivista di Storia Contemporanea, 14: 207-242.

1986 L'Eritrea-Colonia, 1890-1952: paesaggi, strutture, uomini del colonialismo (Milano: F. Angeli).

1988 La memoria dell'Impero (Bari: Lacaita).

1996 Autobiografie africane (Milano: Franco Angeli).

TALAMONA, M.

1985 “Addis Abeba capitale dell'impero", Storia contemporanea, 16 (5-6): 1093-1130.

TALHAMI, G. H.

1978 "Massawa under Khedive Ismail, 1865-1879", in Proceedings of the Fifth International Conference of Ethiopian Studies Session B, 13-16 April 1978, Chicago, Chicago: University of Chicago): 481-492.

1979 Suakin and Massawa under Egyptian Rule, 1865-1885 (Washington: University Press of America).

\section{TEKESTE NEGASH}

1986 No Medicine for the Bite of a White Snake: Notes on Nationalism and Resistance in Eritrea 1890-1940 (Uppsala: University of Uppsala).

1987 Italian Colonialism in Eritrea (1882-1941) (Uppsala, Uppsala University).

1997 The Federal Experience (Uppsala: Nordiska Afrikainstitutet).

TESHOME WAGAW

1979 Education in Ethiopia (Ann Arbor: University of Michigan Press). 
Тном, М.

1990 "Tribes within Nations: The Ancient Germans and the History of Modern France", in H. K. B HABA (ed.), Nation and Narration (London-New York: Routledge): 23-43.

TRACCHIA, R.

1940 Coloniali e ascari (Milano: Ceschina).

TRINGALI, G.

1973-1977 “Necropoli di Cascassè e oggetti sudarabici dalla regione di Asmara (Eritrea)", Rassegna di Studi Etiopici, 26: 47-98.

TUCCIMEI, E.

1999 La Banca d'Italia in Africa (Bari: Laterza).

ULLENDORF, E.

1960 The Ethiopians: An Introduction to Country and People (London: Oxford University Press).

ULLENDORFF, E. et al. (eds.)

1971 “Habash, Habasha”, Encyclopaedia of Islam (Leiden: Brill): 3-9.

UOLDELUl CHELATi DiRAR

1996 L'Africa nell'esperienza coloniale italiana: la Bibioteca Guerrino Lasagni (1915-1991) (Bologna: Il Nove).

VALLAURI, L.

1939 Arrai. Con le bande armate in Etiopia (Roma: Edizioni Roma).

VALUSSI, P.

1868 "Le piccole città nel nuovo ordinamento d'Italia", La Nuova antologia, 8 (luglio): 541-559.

VitAle, M. A.

1960 L'opera dell'Esercito (1885-1943), in L'Italia in Africa, serie Storico-militare, Vol. I (Roma: Istituto Poligrafico dello Stato).

WATSON, R.

1999 "Ibadan: A Model of Historical Facts: Militarism and Civic Culture in a Yoruba City", Urban History, 26 (1): 5-26.

WENIG, S.

1997 "German Fieldwork in Eritrea", Nyame Akuma, 48: 20-21.

WRIGHT, G.

1991 The Politics of Design in French Colonial Urbanism (Chicago: Chicago University Press).

WYLDE, A. B.

1970 [1901] Modern Abyssinia (Westport: Negro Universities Press).

YEMANE MESGHENNA

1988 Italian Colonialism: A Case Study of Eritrea, 1869-1934 (Lund: University of Lund).

YOHANNES OGBAZGHI

1991 Eritrea: A Pawn in World Politics (Gainesville: University of Florida Press).

YSHAQ YOSEF

1993 Zanta kätäma Asmära (Addis Ababa: no publisher).

ZAGNONI, S.

1993 “L'Eritrea delle piccole città, 1897-1936", in G. GRESLERI, P. G. MASSARETTI \& S. ZAGNONI

(eds.), Architettura italiana d'oltremare (Venezia: Marsilio). 
ZOPPI, A.

1935 "Baldissera fondatore della Colonia Eritrea", Illustrazione coloniale, 5.

\section{NOTES}

*. A draft version of this article was first presented at the international Workshop on "Urbanism and urbanisation in Eastern Africa, c.18 ${ }^{\text {th }}$ century to 1980 ", organised in Nairobi (2-4 July 2001) by the British Institute for East Africa, to which I am deeply grateful for the financial and academic support it provided to my research. I am also most grateful to all friends and colleagues who patiently read this article and enriched it with their precious comments.

1. Ascari derives from the Arabic 'askari, which means soldier.

2. I am referring here to the well-established scholarly tradition developed both by Ethiopian scholars and Western Ethiopianists which describes the history of the region in terms of a continuous and consistent process of development of the Ethiopian nation-state from antiquity till the present time. Significant examples of this tradition are E. ULLENDORF (1960) S. RUBENSON (1976), GetacheW Haile (1986).

3. The latest developments of this theoretical approach could be found in the publications of $T$ eKeste Negash (1997), Alemseghed Abbay (1998) and P. HenZe (2000).

4. An interesting discussion of pre-colonial urbanism in Africa in C. COQUERY-VIDROVITCH (1992). For an updated analysis of urban history in Easter Africa see the Proceedings of the workshop on "Urbanism in Eastern Africa" edited by A. BURTON (2001-2002).

5. For a critical discussion of the development of Eritrean historiography, see BAIRU TAFLA (1994).

6. Relevant exceptions are R. PANKHURST (1982) and G. GRESLERI et al. (1993), which both cover important aspects of Eritrea's urban history. Up to now the scholarly production on architectural and urbanistic aspects of Italian colonialism tended to focus more on the fascist period giving, therefore, priority to the "Imperial" architecture developed in Ethiopia, see M. TALAMONA (1985), A. BORALEVI (1986) and M. FulLeR $(1991,1996)$. However, a new season of research focused on a more global approach to the urban history of Eritrea seems to unfold in the last recent years. I would like to mention the research project launched in 1997 by the Faculty of Architecture of the University of Torino, under the supervision of Anna Gilibert and focused on the training and activity of Italian architects and engineers working in Eritrea between 1907-1920. Unfortunately the project has been interrupted because of the Eritreo-Ethiopian conflict of 1998-2000 but there is hope that it will continue. Also very promising is the research project on the urban history of Asmara carried out by Francesca Locatelli, a PhD candidate at soAs focusing on gender, race and urban space. Impressive is also the material presented in E. DENISON et al. (2003).

7. Indeed colonial literature did not entirely deny the existence of urban developments in ancient times but tended to attribute it mainly to the influence of foreign civilisations, particularly from the Arab Peninsula (ConTI Rossini 1928: 99-111).

8. The Italian colonial officer and scholar Ruffillo Perini, on the basis of oral tradition he collected in the area, suggests a later period for the arrival of the Chewa, which he dates back to the $17^{\text {th }}$ century (PERINI 1905: 65).

9. The Italian scholar A. POLLERA (1935: 120) identified the existence of 66 villages whose origin was attributed to those military settlements.

10. To this regard an important theme in the history of the region, which has not been fully analysed yet, is the role of Muslim trading communities in the growth of urban centres. Important contributions in this direction in M. ABIR (1966), R. PANKHURST (1984), HuSSEIN AHMED (1985, 2001), J. MiRAN [Forthcoming 2004].

11. On Egyptian ambition in the region see G. H. TAlhami (1979) and Adhana Mengsteab (1990). 
12. Sheftennät derives from the root shäffäta which means to rebel against the authority. Sheftas in the local tradition refers both to common bandits as well as to the romantic character of the "social bandit" discussed by НовSваwм (1969). On the social and political implication of this form of banditry see R. CAULK (1984) and T. FERNYHOUGH (1986).

13. A partial exception can be found in the town of Massawa, which, under Egyptian occupation, experienced a process of substantial development of its infrastructures as well as of its economic activities in general (ODORIZZI 1911: 118-120; TALHAMI 1978).

14. F. MARTINI (1895: 38-40) reporting about his visit to Eritrea made in 1891, provides a vivid and appalling description of the masses of starving people coming from the region of Tegray who were dying of starvation and consumption at the outskirts of Massawa.

15. On the relationship between geography and Italian colonial conquests see E.CASTI MORESCHI (1998) and GAMBI (1994).

16. Later on the fort was renamed Fort Baldissera, in honour of the Italian general responsible for military operations in the Colony (BIzZoNi 1897: 335).

17. Member of the Italian Parliament and former Minister of Education, Ferdinando Martini was initially a strong opponent of Italian colonial involvement in the region. It was only after his visit to Eritrea in 1891 as member of the Commission of Enquiry set up by the Italian Parliament that he changed his attitude and started supporting the cause of Italian colonial expansionism. On Martini colonial policies see the collection of articles by A. AQUARONE (1989).

18. The transfer of the capital of the colony to Asmara was not the result of a formal deliberation but was rather a de facto action taken by governor Martini.

19. A detail discussion of financial policies and investments in colonial Eritrea in I. TADDIA (1985).

20. Decreto Governatoriale no. 137 of 3 August 1902, in Bullettin Ufficiale della Colonia Eritrea, 9 August, 1902, no. 32, that included only the first part of the master plan for the town.

21. Decreto Governatoriale no. 196 of 29 April 1903, Bullettino Ufficiale della Colonia Eritrea, 2 May 1903, no. 18.

22. Decreto Governatoriale no. 206 of May 9 1903, Bullettino Ufficiale della Colonia Eritrea, 16 May 1903, no. 20.

23. Decreto Governatoriale no. 798 of 23 October 1908, Bullettino Ufficiale della Colonia Eritrea, 1 November 1908, no. 42.

24. Decreto Governatoriale no. 938 of 16 August 1909, Bullettino Ufficiale della Colonia Eritrea, 1-5 August 1909, no. 33.

25. In a broader context this debate echoed a wider debate developed in European intellectual circles in the 19th century among intellectuals like Renan, Müller, and Burnouf supporting the theory of the determinant role of Aryan nomadic tribes in the development of European civilisation and intellectuals like Cattaneo, Thierry, and Guizot who argued that the Mediterranean urban model, based on communes, was to be considered a key element in the European civilisation (Тном 1990).

26. With regard to British colonial urban planning, Anthony D. KING (1976: 24) speaks in terms of "an example of comprehensive and positive planning theory put into practice by government many decades before this became feasible in the metropolitan society".

27. First conceived by Governor Martini, this decree was developed and finalised later on by his successor Governor Giuseppe Salvago Raggi (ONNIS 1957: 176).

28. In fact, decree 798 provided only a cartographic description of zones 1 and 2, without specifying either their social or racial connotation.

29. The Decreto Governatoriale no. 787 of 8 October 1908 had established that Arabs, Egyptians [sic], and Indians were to be considered as assimilated to the status of colonial subjects. See Bullettino Ufficiale della Colonia Eritrea, 8 October 1908, no. 787. 
30. Decreto Governatoriale no. 814 of 19 December 1908, Bullettino Ufficiale della Colonia Eritrea, 24 December 1908, no. 52 .

31. "Ordinamento fondiario per la Colonia Eritrea", Regio decreto no. 378, 31 January 1909, Bullettino Ufficiale della Colonia Eritrea, 15 July 1909, no. 28.

32. Odoardo Cavagnari was invited to Eritrea by Governor Salvago Raggi in 1911 to carry out feasibility studies for aspects of hydraulic engineering related to agricultural settlements. In 1914 Cavagnari was appointed director of the so-called Ufficio Tecnico of the Municipality of Asmara, the department in charge, among others, of urban planning. It was in this position that he designed the two above-mentioned master plans (PUGLISI 1953: 176).

33. Evidence of this development can be found in the appearance in the urban space of buildings reserved to the financial sector. This is the case of the branches of the Banca d'Italia (Central Bank) opened in Asmara (2 February 1914), Massawa (15 April 1914), Keren (16 August 1917) (T UCCIMEI 1999: 91-94).

34. The organisation of the urban space along racial lines and the use of green areas as territorial markers and barriers between indigenous and European districts is a practice common also to other colonial contexts. An example of this in D. N. RASTER (1973). With regard to French colonial urban planning, interesting analysis in P. RABINOW (1989) and G. WRIGHT (1991).

35. Decreto Governatoriale 21.01.1914 n. 1909, in Bullettino Ufficiale della Colonia Eritrea, 22 January1914, no. 4.

36. To this end, a precious resource is the Bullettino ufficiale delle Colonia Eritrea, which collects all the legislative as well as administrative decisions taken in, or regarding colonial Eritrea. Particularly with regard to building permissions the Bullettino Ufficiale provides detailed information concerning the surface allocated for building purposes, the sum paid for the purchase, as well as the district or region of origin of the purchaser.

37. This interesting phenomenon of substantial involvement of women in the urban growth of colonial Eritrea can be partially explained as a stratagem adopted by Italian officials to circumvent limitations introduced by Art. 158 of the above mentioned "Ordinamento fondiario per la Colonia Eritrea", Regio decreto no. 378 of 31 January 1909. In fact, Art. 158 sanctioned that both civilian and military personnel of the colony were not entitled to apply for whatever form of land concession. Therefore, it seems that a common practice to avoid this legal obstacle was to register land for building purposes under the name of the indigenous partner that many Italian officers and colonial administrators used to have at that time. For this note I am indebted to Fratel Ezio Tonini of the Pavoni Library in Asmara.

38. The son of Maurizio Rava, an important colonial administrator and Governor of Somalia between 1 July 1931 and 7 March 1935, Enrico Rava devoted a great deal of energy to the development of an Italian colonial architecture with its own specific architectural features.

39. It is worth reminding that the hectic activity of urban planning and architectural redefinition of urban space witnessed in the colonial territory during the fascist period, was paralleled by a similarly intense activity in the colonial metropolis. In fact, between 1934 and 1937 authorities in charge of urban planning approved many new master plans for Italian towns and also launched works of substantial architectural reorganisation of urban areas (MIONI 1980).

40. Examples of this attitude in Bosio (1937), Guidi \& VALLE (1937). Indeed fascist architects seem not to have benefited from the scholarly production developed in the "classical" Italian colonial literature, which could have provided them with a better understanding of the local concept of territory and urban space. I think particularly of studies like A. PolleRA (1913) and C. CONTI R OSSINI (1916).

41. However, few critical voices among the choir of fascist architects and urban planners tried to develop a more balanced approach to local architectural and urban traditions. An example of this 
in R. PARTINI (1938). In this article the author points out that the dismissive approach toward indigenous architectural traditions might be a stereotype and as such in need of being revised.

42. Two main episodes gave fascist urban planners the opportunity to redesign Addis Ababa's urban space. The first episode was the flight of the Emperor Haile Sellassie in front of the advancing Italian army, who left the capital in a state of anarchy and at the mercy of looters and arsonists. The second episode was the ruthless retaliation unleashed by the colonial administration against Ethiopian civilians after the attempted assassination of Marshal Graziani in February 1937. Both episodes led to the arson of indigenous districts with the destruction of hundreds of houses (BADOGLIO 1937: 203; PoGGIALI 1971: 182).

43. Cafiero, an architect and member of the Consulta centrale per l'edilizia e l'urbanistica (Central Commission for Urban Planning and Building) was dispatched to Asmara after a master plan previously endorsed by the Colonial administration in Eritrea in 1937 had been invalidated by the Ministero dell'Africa Italiana on charge of procedural irregularities. Documental evidence of this episode in the Central State Archive (ACS) in Rome, see the director of MAI DGAff. Civili [Teruzzi] to Governo Asmara, Concorso piano regolatore centro Asmara, Roma, 29 December 1937, Telegram, ACS-MAI B. 103 f. 2.

44. Instituted in April 1937, the Ministero per l'Africa Italiana reflected a mutated perception of the role of colonial policies in the political vision of the fascist regime. The establishment of the new ministry made official, from an administrative point of view, the existence of large Italian colonial acquisitions in Africa and laid the foundation for their more effective social and economic control (MARINUCCI 1963: 134-136).

45. Actually Amoroso's article is mainly based on a report submitted by architect Cafiero at the meeting of the Consulta Centrale per l'Edilizia e l'Urbanistica held in Rome on 5 April 1939. Copy of this report in the Central State Archive in Rome, Progetto del Piano Regolatore della città di Asmara Arch. Vittorio Cafiero ACS-MAI B. 106 f. 2

46. It is interesting to notice that the Italian scholar, referring to the development of indigenous districts into European areas, uses the verb incunearsi which in Italian means to wedge in, conveying very clearly how uneasy were fascist urban planners in their perception of the contact between colonisers and colonial subjects in urban context.

47. Progetto del Piano Regolatore della città di Asmara Arch. Vittorio Cafiero ACS-MAI B. 106 f. 2.

48. On the contradiction of Italian colonial racism see also: G. CAMPASSI (1987); L. GogliA (1985, 1992: 97-115); F. Le HUEROU (1994); G. BARRERA (1996); B. SORGONI (1998) and RUTH IYOB (2000).

49. The literature dealing with Eritrean ascari can basically be divided into two main categories: colonial and post-colonial. The abundant colonial literature, which as a genre continued largely after the end of Italian colonial rule, produced mainly in form of memoirs by former Italian officers, tends to focus on stereotypic representation of ascari, which are portrayed as loyal and brave servants of the Italian flag. A general patronising attitude is the main feature of this kind of production and little room is given to the analysis of social and cultural issues. On the other side, the scanty post-colonial production tends to focus on a more rigorous historiographic approach, but, unfortunately it is a very limited production (SCARDIGLI 1996), regrettably limited to the early years of Italian colonialism, and based only on archival sources. For a broad overview, see AMANUEL SAHLE (1988). For a brief review of part of the colonial production, see also Uoldelul Chelati Dirar (1996).

50. This theme is partially developed in F. APOLLonio (1993).

51. The name Basci Buzuk is of Turkish origin and meant literally "scatterbrained heads". Originally those soldiers were part of the Ottoman army and were recruited on a local basis. They were mainly utilised for police activities, to collect tributes and to escort Ottoman authorities. C. G. PINI (1912: 75).

52. Regio Decreto no. 707 of 11 December 1892 n. 707, in A. MORI (1914: Vol. II, 555). 
53. G. F. H. B ERKELEY (1969: 345-346), in his detailed analysis of the battle of Adwa estimates losses among ascari in terms of about 2,000 killed and 958 wounded. Moreover, 406 of the Eritrean ascari made prisoners by Menelik were sent back mutilated of their right hand and left foot.

54. To contain the drainage of manpower many of those new battalions were strengthened with the recruitment of troops from neighbouring countries of Ethiopia, Yemen and Sudan.

55. A parallel development that led to a further exasperation of this trend was the outbreak of the First World War which led to an increased need for colonial troops to be dispatched over Italian colonial territory in Northeast Africa.

56. Documentary evidence of this can be found in the correspondence between the Governor of Eritrea Giuseppe Salvago Raggi, the Italian Minister of Foreign Affairs Di San Giuliano, and Ferdinando Martini (at the time minister of colonies) part of which is reproduced in the appendix to M. A. VitAle (1960: 198-204). Mention of this debate also in TeKESTE NeGASH (1987: 50).

57. Pictures of those campi-famiglia in L. Goglia (1998: 239 [pict. VII, 9]) and M. A. Vitale (1960: $112,120)$.

58. The world tucul was borrowed by Italian colonial literature from the Arabic. In fact, in Tigrinya this kind of house was named agdo. It has to be emphasized that dwelling habits of Eritrean highlands tended to consider the agdo mainly as a temporary habitation (CONTI RossinI 1916: 147).

59. Pictures showing this building activity in R. PIANAVIA-VIVALDI (1901: 48-49).

60. This was done in order to minimise costs of production (VITALE 1960: 118).

61. The real dimension of the involvement of ascari and of Eritrean labour at large in building colonial infrastructures remains still a little investigated and controversial topic. JORDAN GEBRE-M EDHIN (1989: 60) seems to support the hypothesis of a massive involvement of Eritreans under schemes of forced labour. However, in his discussion of the subject he does not provide relevant figures and fails to put the phenomenon in an historic perspective. On the opposite, YEMANE M ESGHENNA (1988: 183), in his analysis of colonial economic policies in Eritrea, supports the idea that the involvement of Eritrean labour was probably minimal, due to the massive recruitment in the colonial army, and he suggests a major role to be attributed to migrant labour from neighbouring countries. A similar argument, with abundance of figures, is developed in R.P ANKHURST (1971). This paper deserves special attention because it also analyses in details the involvement of Italian labour in the building of infrastructures during the Fascist period with particular attention to the relations between employers and employees.

62. This activity, though depicted with extremely emphatic and propagandistic words, is documented in a copious literature produced during the colonial period (ARCANGELI 1936; B ATTAGLini 1938; CoBolli Gigli 1938, 1941).

63. In the case of Keren, military fortification were developed over pre-existing Egyptian structures (BIzzoni 1897: 192).

64. The Adi Ugri of colonial sources.

65. General Antonio Baldissera, dispatched to Eritrea in 1887, took part in the main military and diplomatic developments which led to the establishment of Eritrea as an Italian colony. Governor of the colony from 22 February 1896 to 3 March 1897, Baldissera planned the main military and civilian infrastructures of the colon, including Fort Bet Makha'e (PUGLISI 1953: 31).

66. Amba indicates a special orographic conformation of Eritrean and Ethiopian landscapes. It refers to mountains with a flat top and steep slopes.

67. Colonel Giuseppe Galliano, in Eritrea since 1887, took part in many of the colonial battles fought in Eritrea. He had a major role in the battle of Coatit (13 March 1895) and in the siege of Enda Yesus (8 December 1895-21 January 1896). He died in the Battle of Adwa (March 1, 1896). See G. Puglisi (1953: 137). 
68. There is a rich Italian colonial literature dealing with bandas. Among many: L. VALLAURI (1939); A. FERRARI (1940); L. FAZI (1968).

69. Habasha, derives from the Arabic habasha which means immigrants. It is used to indicate the Semitic speakers of both Eritrean and Ethiopian highlands. The origin of this name has been a very debated issue. Colonial literature tended to identify the Habasha with immigrants from the Arab peninsula which would have contributed to the development of local civilisation. More recent scholarly approach tends to suggest the opposite. On the controversial use of the ethnonim Habasha, see CoNTI Rossini (1906), E. ULLENDORFF et al. (1971: 3-9); R. PANKHURST (2002).

70. Y SHAQ YOSEF (1993: 63), on the basis of oral sources, suggests a different origin for this toponym. In fact he affirms that the area takes its name from the presence of officers of the Italian Military police known as Carabinieri who were presumably responsible for sections of the colonial army.

71. For this explanation I am indebted to the deep and meticulous knowledge of my friends and colleagues Giancarlo Stella and Alessandro Volterra.

72. In Tigrinya may means water.

73. Gäbbar from the root gäbära (to pay tribute) in the highlands of Eritrea and northern Ethiopia refers to free peasants who were subject to the payment of tribute. In a broader sense is used to indicate farmers.

74. Decreto Governatoriale no. 181 of 25 March 1903, "Immigrazioni operai, mano d'opera e contratto di lavoro". On this aspect see also I. TADDIA (1986: 255).

75. A first step in this direction was the Gubernatorial proclamation of 20 June 1896, issued by Governor Baldissera. The proclamation stated that loyal ascari had to be rewarded with the allocation of land and houses in abandoned villages. In Bullettino Ufficiale della Colonia Eritrea, 3 July 1895 , no. 77.

76. However, as pointed out to me by my friend and colleague, the late Dr Alexander Naty, this trend can be noticed mainly among some of the different ethnic groups which compose Eritrea. More precisely this tendency toward urbanisation in the colonial time seems to be more common among the inhabitants of Eritrean highlands. On the opposite, some populations like Kunama and Nara appear to have been left more or less extraneous to this phenomenon. An interpretation of this phenomenon can be the fact that in the western lowlands of Eritrea, where those populations are traditionally settled, there was much less demographic pressure and, consequently, fewer problems in accessing the land. Therefore, the push toward urbanisation was irrelevant. This can explain why very few members of those communities were absorbed in the colonial administration and even those who served as ascari, after their draft went back to their previous rural style of life.

77. It is worth noticing how those policies contradicted the main practice in use in the colonial metropolis where normally Italian officers and soldiers were discouraged from having family ties (Del Negro 1988; CARdoza 1989).

78. For the etymology of this word which in Italian means little evils, R. PIANAVIA-VIVALDI (1901:

34) suggests that its use in Eritrea derived rather from an Italian adaptation, by assonance, of the Arabic walad (pl. awlad), which means boys and commonly used in Massawa.

79. On the indigenous tradition of titles, see Ayele TeкLe-Haymanot (1965).

80. Commander of a thousand men. This title was given after ten years of service.

81. Commander of fortified places. This title was given after ten years of service.

82. This title, which in Saho language correspond to "chief of a tribe" or of a section of a tribe, was given only to Muslim soldiers and was an equivalent of balambaras.

83. Commander of the left wing of the Army. This title was given to already decorated soldiers, after fifteen years of service. 
84. Commander of the vanguard. This title was given to already-decorated soldiers after twenty years of service.

85. Mäskäl, is the festivity of the Cross which the Orthodox tradition associates with the arrival of a relic from the Cross of Jesus Christ. This festivity also marks the end of the rainy season and has therefore an apotropaic function as auspices of fertility for the land (POLLERA 1926: 308-309).

86. Those festivities were sanctioned as official holidays of the colony by the Decreto Governatoriale no. 1628 of 10 September 1912, in Bullettino Ufficiale della Colonia Eritrea, 12 September 1912, no. 37.

87. Waiting for more detailed investigations, empirical evidences of ascari's role as nuclei of an Eritrean urban elite can be found looking at biographical dictionaries (PUGLISI 1953; KILLION 1998; RossinI 1989). Another precious source of information is I. TADDIA (1996).

88. Some general reference to this theme in F. LE HUEROU (1999). A more complete discussion of the emergence of a germinal Eritrean bourgeoisie in the last period of Italian colonial rule in $\mathrm{T}$ ADDIA (1986: 263).

89. It has to be recollected that a few decades earlier, after its unification, Italy had undergone a similar process of nation building which saw the involvement of the army as one of the privileged lieu where to weld the Italian national identity. Even more important is the fact that many of the officers involved in the colonial experience had been actively involved in that process in the motherland (GoocH 1989: 9).

90. Regolamento di disciplina per i militari indigeni del Regio Corpo di truppe Coloniali d'Eritrea, Art. 9, pars. 33-34.

91. Ibid., Art. 8, par. 32.

92. Ibid., Art. 6, par. 24.

\section{ABSTRACTS}

In the process of urbanisation experienced by Eritrea, between 1890 and 1941, under Italian colonialism a major role was played by the military component. Military priorities were crucial in determining lines of development in the early colonial urban planning in Eritrea as the criteria of military defensibility, rather than economic or functional priorities, had significantly influenced the main patterns of early colonial settlements in the region. The military factor was also important in determining the nature and extent of the interaction between colonial urban planning and Eritrean society. In this process a major role was played by Eritrean colonial troops, known as ascari. In virtue of their close relation with the colonial authority ascari became a sort of buffer between colonized and colonizers and, therefore, were partially involved in the colonial strategy aimed at reshaping the social and economic landscape of Eritrea. Ascari were instrumental in the colonial attempt to set up the composite set of relations and strategies which constituted the colonial milieu. Urban history of colonial Eritrea represents one of the ideal subjects for the study of the development of the colonial society in which colonial soldiers were important actors as builders of social and territorial urban spaces.

Le facteur militaire a joué un rôle important dans le processus d'urbanisation de l'Érythrée entre 1890 et 1941, pendant la période coloniale italienne. Les priorités militaires ont été plus déterminantes que les priorités économiques ou fonctionnelles dans le choix des lignes de développement dans l'urbanisme des débuts de la colonie. Le facteur militaire a également été 
décisif pour déterminer la nature et l'étendue de l'interaction entre l'urbanisme colonial et la société érythréenne. Les troupes coloniales érythréennes, connues sous le nom d'ascaris ont joué un rôle majeur dans ce processus. Du fait de leurs relations étroites avec les autorités, les ascaris sont devenus une sorte de tampon entre les colonisateurs et les colonisés et, pour cette raison, ont été en partie impliqués dans la stratégie coloniale qui visait à redéfinir le paysage économique et social de l'Érythrée. Les ascaris ont joué un rôle décisif dans la tentative menée par les autorités coloniales de mettre en place un ensemble de relations et de stratégies qui ont constitué le milieu colonial. L'histoire urbaine de l'Érythrée représente un sujet idéal pour l'étude du développement de la société coloniale dans laquelle les soldats coloniaux ont été des acteurs importants en tant que créateurs d'espaces urbains sociaux et territoriaux.

INDEX

Keywords: army, ascari, colonialism, colonial troops, elites, Italian colonialism, racism, toponymy, urban planning, urbanisation

Mots-clés: armée, ascaris, colonialisme, troupes coloniales, élites, colonialisme italien, racisme, toponymie, urbanisme, urbanisation

Geographical index: Eritrea, Érythrée

\section{AUTHOR}

UOLDELUL CHELATI DIRAR

University of Asmara. 